\title{
1 Dissolved amino acids in oceanic basaltic basement fluids
}

3 Huei-Ting Lin ${ }^{\mathrm{a}^{*}}$, Jan P. Amend ${ }^{\mathrm{b}, \mathrm{c}}$, Douglas E. LaRowe ${ }^{\mathrm{b}}$, Jon-Paul Bingham ${ }^{\mathrm{d}}$, James P. 4 Cowen $^{\mathrm{a}^{* *}}$

$6{ }^{a}$ Department of Oceanography, School of Ocean and Earth Science and Technology,

7 University of Hawaii, 1000 Pope Road, Marine Science Building 205, Honolulu, HI 896822 , U.S.A.

$9{ }^{b}$ Department of Earth Sciences, University of Southern California, 3651 Trousdale 10 Pkwy., Los Angeles, CA 90089, U.S.A.

$11{ }^{\mathrm{c}}$ Department of Biological Sciences, University of Southern California, Alfred Hancock 12 Foundation Building, Los Angeles, CA 90089, U.S.A.

$13{ }^{\mathrm{d}}$ Department of Molecular Biosciences and Bioengineering, University of Hawaii, 3190 14 Maile Way, Honolulu, HI 96822, U.S.A.

$15 *$ Corresponding author: Huei-Ting Lin hueiting@ hawaii.edu

16 (Phone) +1-808-225-5809 (Fax) +1-808-956-9225

17 Amend: janamend@usc.edu

18 LaRowe: larowe@usc.edu

19 Bingham: jbingham@hawaii.edu

$20 * *$ Cowen: Deceased

21 Key words: dissolved amino acids, deep subseafloor biosphere, degradation of organic

22 matter, heterotrophic activity, energetics of amino acids, sorption and desorption

(C) 2015. This manuscript version is made available under the Elsevier user license http://www.elsevier.com/open-access/userlicense/1.0/ 


\section{Abstract}

24 The oceanic basaltic basement contains the largest aquifer on Earth and potentially plays

25 an important role in the global carbon cycle as a net sink for dissolved organic carbon

26 (DOC). However, few details of the organic matter cycling in the subsurface are known

27 because great water depths and thick sediments typically hinder direct access to this

28 environment. In an effort to examine the role of water-rock-microorganism interaction on

29 organic matter cycling in the oceanic basaltic crust, basement fluid samples collected

30 from three borehole observatories installed on the eastern flank of the Juan de Fuca Ridge

31 were analyzed for dissolved amino acids. Our data show that dissolved free amino acids

32 (1-13 $\mathrm{nM})$ and dissolved hydrolyzable amino acids (43-89 $\mathrm{nM}$ ) are present in the

33 basement. The amino acid concentrations in the ridge-flank basement fluids are at the low

34 end of all submarine hydrothermal fluids reported in the literature and are similar to those

35 in deep seawater. Amino acids in recharging deep seawater, in situ amino acid production,

36 and diffusional input from overlying sediments are potential sources of amino acids in the

37 basement fluids. Thermodynamic modeling shows that amino acid synthesis in the

38 basement can be sustained by energy supplied from inorganic substrates via

39 chemolithotrophic metabolisms. Furthermore, an analysis of amino acid concentrations

40 and compositions in basement fluids support the notion that heterotrophic activity is

41 ongoing. Similarly, the enrichment of acidic amino acids and depletion of hydrophobic

42 ones relative to sedimentary particulate organic matter suggests that surface sorption and

43 desorption also alters amino acids in the basaltic basement. In summary, although the

44 oceanic basement aquifer is a net sink for deep seawater DOC, similar amino acid

45 concentrations in basement aquifer and deep seawater suggest that DOC is preferentially 
46 removed in the basement over dissolved amino acids. Our data also suggest that organic

47 carbon cycling occurs in the oceanic basaltic basement, where an active subsurface 48 biosphere is likely responsible for amino acid synthesis and degradation. 


\section{Introduction}

Containing a volume of hydrothermal fluids equivalent to $\sim 2 \%$ of the global

51 ocean (Johnson and Pruis, 2003), the upper 40-500 m of basaltic ocean basement is the

52 largest aquifer on Earth (Fisher, 2005). The basement fluids are not stationary: the flux of

53 hydrothermal water through ridge flanks — crustal age older than 1 million years — is

54 estimated to be equivalent to $5-60 \%$ of the global riverine input of water into the ocean

55 (Mottl, 2003; Wheat et al., 2003). The hydrothermal flux is sufficiently large that the

56 entire ocean is recycled through the basaltic basement once every 100,000 to 500,000

57 years (Fisher, 2005). Thus, the circulation of deep ocean water through submarine

58 hydrothermal systems plays an important role in global biogeochemical cycles, including

59 the global carbon cycle. This is due to the fact that there is nearly as much fixed carbon

60 as dissolved organic carbon (DOC) in the deep ocean (>1000m; 662 Pg C; Hansell et al.,

61 2009) as there is $\mathrm{CO}_{2}$ in the atmosphere (750 Pg C; Siegenthaler and Sarmiento, 1993),

62 and that seawater DOC is removed during its flow path in the basement (Lang et al., 2006;

63 Lin et al., 2012).

Biological activity in the subsurface has been suggested to play a role in DOC

65 removal (Lang et al., 2006; Lin et al., 2012). There are several lines of evidence,

66 including the texture, chemical, and isotopic composition of both basaltic glass and rocks,

67 suggesting the existence of biological activity within the ridge-flank basement

68 (Giovannoni et al., 1996; Fisk et al., 1998; Furnes et al., 2006; Rouxel et al., 2008; Wheat

69 et al., 2010; Alford et al., 2011; Alt and Shanks, 2011; Ono et al., 2012). Fluids sampled

70 from the ridge-flank aquifer have yielded ribosomal RNA gene sequences related to

71 chemolithoautotrophs and heterotrophs, and functional genes of sulfate reducers, 
72 indicating the presence of a diverse bacterial and archaeal community (Cowen et al.,

73 2003; Huber et al., 2006; Jungbluth et al., 2013; Robador et al., 2015). However, these

74 genomic data do not necessarily reveal what, if any, heterotrophic activity is ongoing in

75 this environment. In addition, although few studies have investigated the energetic

76 potential for chemolithoautotrophic metabolisms in the oceanic basaltic aquifer (Bach

77 and Edwards, 2003; Lin et al., 2012; Boettger et al., 2013), there is no investigation

78 focused specifically on understanding the energetic cost of synthesizing or the yield from

79 degrading key biomolecules such as amino acids.

As the building blocks of all proteins and potential sources of carbon, nitrogen,

81 and energy, amino acids (AAs) are one of the most bio-utilizable (or labile) organic

82 substrates in aqueous environments (Crawford et al., 1974; Wheeler and Kirchman, 1986;

83 Fuhrman, 1987; Keil and Kirchman, 1991b; Middelboe et al., 1995; Ouverney and

84 Fuhrman, 2000). Although many microorganisms isolated from hydrothermal

85 environments have been shown to actively take up AAs (Jannasch et al., 1988; Pledger

86 and Baross, 1991; Hoaki et al., 1993; Hoaki et al., 1994; Dirmeier et al., 1998), the

87 distribution and abundance of AAs within hydrothermal ecosystems have only been

88 documented in a few studies (Haberstroh and Karl, 1989; Takano et al., 2003; Svensson

89 et al., 2004; Klevenz et al., 2010; Lang et al., 2013). In addition, due to preferential

90 removal and transformation of various AAs during microbial organic matter degradation,

91 the compositions of protein-forming and non-protein forming AAs can be used to

92 examine the diagenetic status of organic matter to infer the occurrence of heterotrophic

93 activities in an environment (Hecky et al., 1973; Cowie and Hedges, 1992; Dauwe et al.,

94 1999; Heeschen et al., 2003; Aluwihare and Meador, 2008). This status, however, has not 
95 yet been documented for any submarine hydrothermal environment, largely due to the

96 difficulty of obtaining fluid samples from the deep subseafloor.

97 Recent advances in the installation of Circulation Obviation Retrofit Kit 98 observatories (CORKs) into Integrated Ocean Drilling Program (IODP) boreholes have

99 provided unprecedented access to the deep basaltic basement. In an effort to study water-

100 rock-microorganism interactions on organic matter cycling, we use the concentration and

101 composition data of dissolved AAs in ridge-flank basement fluids to infer processes

102 involving AA cycling in the basaltic basement. To provide context, the AA data are

103 compared to the concentrations of AAs in other submarine hydrothermal systems and

104 deep seawater. Thermodynamic calculations are presented to evaluate the energetics of

105 AA syntheses in the basement. Several established AA-based degradation indices are also

106 calculated to examine the digenetic status of organic matter in basement fluids.

107 2. Methods and materials

$108 \quad 2.1$ Sampling methods

109 Pristine basement fluid samples were collected from CORKs installed at IODP 110 Holes U1301A, U1362A, and U1362B located on the eastern flank of Juan de Fuca Ridge 111 off the western coast of North America (Figure 1). Penetrating through $\sim 250 \mathrm{~m}$ of 112 sediment into the $\sim 3.5$ million year old basement, the three CORKs are equipped with 113 fluid delivery lines made of polytetrafluoroethylene (1362A and 1362B) or stainless steel 114 (1301A; Shipboard Scientific Party, 2004; Expedition 327 Scientists, 2010). Based on 115 geochemical composition, basement fluid samples collected using a clean pumping 116 system via fluid delivery lines are superior to those flowing through the reactive, rusty 
117 iron casing found in most CORKs (Cowen et al., 2012; Lin et al., 2012). The three sites

118 are within a radius of $1 \mathrm{~km}$ and have fluid intake depths at $30 \mathrm{~m}$ (1301A), $40 \mathrm{~m}(1362 \mathrm{~B})$,

119 and $200 \mathrm{~m}$ (1362A) below the sub-basement, allowing for the investigation of spatial

120 differences in labile organic carbon cycling. Sampling methods for basement fluid used

121 in this study are described in Cowen et al. (2012) and Lin et al. (2012). Briefly, a mobile

122 pumping system (MPS), transported and powered by the remotely operated vehicle (ROV)

123 Jason or the human-occupied vehicle (HOV) Alvin was used to pump the fluid up

124 through CORKs' fluid delivery lines and into $60 \mathrm{~L}$ Tedlar (polyvinyl fluoride) bag

125 samplers (LVBS) in 2009 and 2010 from CORK 1301A, and 15 L foil-lined, gamma

126 irradiated polyethylene inner-liner bag samplers (MVBS) from CORKs 1301A, 1362A

127 and 1362B in 2011. Aliquots of basement fluids were subsampled into acid-cleaned, 20

$128 \mathrm{~mL}$ combusted $\left(550^{\circ} \mathrm{C}\right.$, five hours) glass scintillation vials once the LVBS or MVBS

129 were shipboard. Subsampling was conducted inside a laminar flow hood with a high-

130 efficiency particulate air filter. The fluid samples were then stored frozen at $-20^{\circ} \mathrm{C}$ until

131 analysis. Sampling blanks, including LVBS and MVBS sampling and shipboard

132 subsampling made by processing deionized water, do not show significant AA 133 contamination.

\subsection{Amino acids analysis}

\subsubsection{Hydrolysis}

Fluid samples were hydrolyzed to break down dissolved combined AAs (DCAAs),

137 such as peptides and small proteins, into free AAs for quantification. In order to facilitate 138 comparison of AA concentration to those reported in the literature, the concentrations of 
139 total dissolved hydrolysable amino acids (DHAAs) are taken to be the sum of dissolved 140 free amino acids (DFAAs, measured without hydrolysis) and DCAAs. Vapor phase

141 hydrolysis was performed using a modified procedure described by Keil and Kirchman 142 (1991b) with a vacuum-heating hydrolysis system (PicoTag ${ }^{\mathrm{TM}}$, Waters). A $100 \mu \mathrm{L}_{\text {fluid }}$ 143 sample was pipetted into a muffled $1 \mathrm{~mL}$ glass insert and placed into a $40 \mathrm{~mL}$ hydrolysis 144 reaction vessel where samples were dried under vacuum $\left(<80 \times 10^{-6}\right.$ bar $)$. Then, $2.1 \mathrm{~mL}$ of $1457 \mathrm{~N} \mathrm{HCl}, 10 \% \mathrm{v} / \mathrm{v}$ trifluoroacetic acid with $0.1 \% \mathrm{v} / \mathrm{v}$ phenol was added to the reaction 146 vessel. Samples were hydrolyzed in the vapor phase at $156^{\circ} \mathrm{C}$ for 23 minutes under an 147 anoxic nitrogen atmosphere. After hydrolysis, samples were dried under vacuum to 148 remove the acid, and the hydrolysate was dissolved in $100 \mu \mathrm{L}$ deionized water for 149 subsequent free AA analysis by HPLC.

\subsubsection{Amino acid characterization and quantification}

Characterization and quantification of AA concentrations were carried out in an

152 automated High Performance Liquid Chromatography (HPLC) system (Alliance 153 Separation Module 2690, Waters). The stationary phase was a $2.1 \mathrm{~mm} \times 150 \mathrm{~mm}$ 154 Hypersil Gold column packed with $3 \mu \mathrm{m} \mathrm{C}-18$ spheres (Thermo Scientific). The $\mathrm{pH}$ was 155 first adjusted by adding a one-to-ten volume ratio of borate buffer $(0.4 \mathrm{M}, \mathrm{pH} 10.5)$ into 156 the sample (Grasshoff et al., 1999; Svensson et al., 2004). Then, an o-phthalaldehyde 157 derivatization reagent $(100 \mathrm{mg}$ of o-phthalaldehyde in $0.5 \mathrm{~mL}$ methanol and $0.05 \mathrm{~mL}$ of 158 2-mercaptoethanol) was added into $\mathrm{pH}$-adjusted samples at a 1:100 ratio (Grasshoff et al., $1591999)$ by the auto-sampler and allowed to react with the sample for exactly 10 minutes; $16030 \mu \mathrm{L}$ of derivatized sample were then injected into the separation column. 
The mobile phases of the separation were $20 \mathrm{mM}$ sodium acetate trihydrate with $0.3 \% \mathrm{v} / \mathrm{v}$ tetrahydrofuran $(\mathrm{pH}$ adjusted to 7.1 using $2 \% \mathrm{v} / \mathrm{v}$ acetic acid) and $100 \%$

163 methanol. The gradient started with $15 \%$ methanol and increased to $18 \%$ in the first 4 164 minutes. Then methanol increased to $22 \%$ at 6.7 minutes, $38 \%$ at 25 minutes, $50 \%$ at 40 165 minutes and $100 \%$ at 47 minutes. The gradient was followed by 7 minutes of $100 \%$ 166 methanol for column cleanup. The gradient was returned to initial conditions (15\% 167 methanol) for 6 minutes to equilibrate the column for the next analysis. This gradient 168 system can separate 15 protein-forming AAs (aspartic acid, glutamic acid, serine, 169 histidine, glycine, threonine, arginine, alanine, tyrosine, methionine, valine,

170 phenylalanine, isoleucine, leucine, and lysine, see Figure 2) and two non-protein-forming 171 AAs ( $\gamma$-aminobutyric acid and $\beta$-alanine). The o-phthalaldehyde derivatized AAs were 172 detected by a fluorescence detector (RF-20Axs, Shimadzu) with excitation and emission 173 wavelengths set at $340 \mathrm{~nm}$ and at $420 \mathrm{~nm}$, respectively. Please refer to the Appendix for 174 details on detection limits (Table A1), blanks (Table A2 and A3) and peak assignments 175 (Table A4).

\subsubsection{Calibration and limits of detection} Calibrations of AAs were made with mixed Amino Acid Standard-H, $\gamma$ 178 aminobutyric acid and $\beta$-alanine standards (Thermo Scientific Pierce). Since tryptophan 179 degraded (e.g. Coffin, 1989), asparagine turned into aspartic acid, and glutamine turned 180 into glutamic acid during acid hydrolysis (e.g. Keil and Kirchman, 1991b), these three 181 AAs were not calibrated and reported. Limits of detection (signal to noise ratio $=3$ ) were 182 smaller than 3-30 fmol, which is equivalent to $0.1-1 \mathrm{nM}$ at the $30 \mu \mathrm{L}$ injection volume for 
183 individual AAs. Reagent blanks were estimated by analyzing deionized water every day

184 and were $0.1-3 \mathrm{nM}$ of individual AAs. The reagent blank was subtracted from the DFAA

185 measured on the same day since o-phthalaldehyde reagent was made daily. Hydrolysis

186 blanks monitored for each batch of hydrolysis ranged from 16-42 nM total AAs and were

187 subtracted from the samples hydrolyzed at the same time. Lysine was much less sensitive 188 than all other AAs using the chosen column and derivatization reagent and had a limit of 189 detection of $\sim 10 \mathrm{nM}$.

$190 \quad$ 3. Calculations

191

\subsection{Thermodynamic calculations}

Gibbs energies of reaction $\left(\Delta G_{r}\right)$ are calculated as

$193 \Delta G_{r}=\Delta G_{r}^{0}+R T \ln Q_{r}$,

194 where $\Delta G_{r}{ }^{0}$ stands for the standard molal Gibbs energy of each reaction at the 195 temperature and pressure of interest, $R$ and $T$ refer to the gas constant and temperature in 196 Kelvin, respectively, and $Q_{r}$ represents the reaction quotient, which is calculated using

$197 Q_{r}=\Pi\left(a_{i}^{v_{i, r}}\right)$

198 where $a_{i}$ denotes the activity of chemical species $i$, and $v_{i, r}$ represents its stoichiometric 199 coefficient. Activities were calculated using the concentrations of the species and their 200 individual ion activity coefficients, which were in turn calculated using an extended 201 version of the Debye-Hückel equation (Helgeson, 1969) and Geochemist's Workbench at 202 the in situ temperature. Values of $\Delta G_{r}{ }^{0}$ at the in situ temperature $\left(65^{\circ} \mathrm{C}\right)$ and pressure 203 (270 bar) were computed using the revised HKF equations of state (Helgeson et al., 1981; 
204 Tanger and Helgeson, 1988; Shock et al., 1992), the SUPCRT 92 software package 205 (Johnson et al., 1992), and thermodynamic data taken from the literature (Shock and 206 Helgeson, 1988; Shock et al., 1989; Amend and Helgeson, 1997; Schulte et al., 2001; 207 Dick et al., 2006; LaRowe and Dick, 2012). The reactions describing the synthesis of 208 AAs and the respective equilibrium constants, $K$, used for thermodynamic calculation are 209 listed in Table 1. Values of $K$ are related to $\Delta G_{r}{ }^{0}$ through

$210 \Delta G_{r}^{0}=-2.3 R T \log \mathrm{K}$

211 The physical and geochemical data used to calculate values of $Q_{r}$ are shown in Table 2 .

212 The average concentrations of detected DFAA, major ions, ammonium, bicarbonate and 213 sulfide reported in Table 3 were used in these calculations. For the undetected DFAA, 214 concentrations were set to their quantification limits. Activities of $\mathrm{H}_{2}$ in ridge-flank 215 basement fluids were computed from concentrations $(0.05-1.8 \mu \mathrm{M})$ reported previously 216 (Lin et al., 2012 and Lin et al., 2014).

\subsection{Degradation Index}

To infer the degree to which organic matter has degraded, the proportions of AAs 219 in a given sample are compared to the abundance of AAs in reference organic materials. 220 The resulting Degradation Index (DI) is calculated using (Dauwe et al., 1999):

221 DI $=\sum_{i}\left[\frac{\operatorname{var}_{i}-\mathrm{AVGvar}_{i}}{\mathrm{STDvar}_{i}}\right] \times{\text { fac } \text { coef }_{i}}$

222 where $\operatorname{var}_{i}$ represents the mole percentage of the $i$ th AA, AVGvar ${ }_{i}$ and STDvar ${ }_{i}$ refer to 223 the mean and standard deviation of the data set, respectively, and fac $\operatorname{coef}_{i}$ corresponds to 
224 the factor coefficient for the $i$ th AA. Factor coefficients (Table A5) used here are the

225 unrotated loadings from principle component analysis based on a dataset covering the

226 possible range of degradation states in marine dissolved organic matter (DOM, Kawasaki

227 and Benner, 2006; Davis and Benner, 2007; Kaiser and Benner, 2008; Kaiser and Benner,

228 2009). DOM-based factor coefficients are used instead of the original particulate-organic-

229 matter-based factor coefficients reported in Dauwe et al. (1999) because AA

230 compositions in DOM are not comparable to AA compositions in particulate organic

231 matter (Kaiser and Benner, 2009). In this study, fresh marine-algal-derived DOM (Amon

232 et al., 2001) and North Atlantic surface and deep seawater DOM (Kaiser and Benner,

233 2009) are used as references for diagenetically unaltered, slightly altered and extensively

234 altered DOM, respectively, for comparison with basement fluid DOM in Eq. (4). Note

235 that the DI values of a sample can only be compared with those included in the same data

236 set used for the calculation; in other words, we cannot compare the DI values calculated

237 here with those reported in literature such as Dauwe et al. (1999).

$238 \quad 4 . \quad$ Results and discussion

\subsection{Concentrations of amino acids in basement fluids}

240 The concentrations of DFAA and DHAA represent the extent to which amino acid 241 production exceeds or lags behind amino acid removal. In order to infer mechanisms 242 controlling AAs, concentrations of DFAA and DHAA in basement fluids are compared 243 with those in fluids from various hydrothermal ecosystems and deep seawater reported in 244 the literature (Table 5). Except for undetectable DFAA $(<0.001 \mu \mathrm{M})$ in the Guaymas 245 Basin vent fluid, concentrations of DFAA (0.001-0.014 $\mu \mathrm{M})$ and DHAA (0.043-0.089 $246 \mu \mathrm{M}$, Table 4) in the basement fluid samples were at the low end of those in any other 
247 non-ridge-flank submarine hydrothermal vent fluids (Table 5, DFAA 0.035-78 $\mu \mathrm{M}$;

248 DHAA 0.067-35 $\mu$ M; Svensson et al., 2004; Klevenz et al., 2010; Lang et al., 2013) and

249 were much lower than those in hydrothermally-influenced sediment porewater samples

250 (DFAA 0.27-446 $\mu \mathrm{M}$; DHAA 0.8-338 $\mu \mathrm{M}$; Haberstroh and Karl, 1989; Hoaki et al.,

251 1995). The low DHAA concentrations in the basement fluids are, however, within the

252 range of those in the deep seawater (0.05-0.18 $\mu \mathrm{M}$, Lee and Bada, 1975; Druffel et al.,

253 1992; Kaiser and Benner, 2009).

254 The undetectable DFAA in the Guaymas Basin fluids have been explained as the 255 result of the instability of amino acids at extremely high temperatures and pressure 256 (Haberstroh and Karl, 1989). Such an interpretation is confirmed by laboratory 257 experiments that show complete decomposition of amino acids at $250^{\circ} \mathrm{C}$ after 240 hours 258 (Ito et al., 2006). Although the same amino acid decomposition experiment did not cover 259 the temperature of our study sites $\left(65^{\circ} \mathrm{C}\right)$, much less decomposition was observed in the 260 same study at $100^{\circ} \mathrm{C}$ than at higher temperatures (Ito et al., 2006). We infer that complete 261 thermal decomposition of amino acids is minor at the modest temperatures $\left(65^{\circ} \mathrm{C}\right)$ within 262 the ridge-flank basement environment; thus, the presence of DFAA is not surprising. 263 However, higher concentrations of DFAA in the mid-Atlantic high temperature vent fluid 264 samples (Table 5) than those in the basement fluids are unexpected as heat degradation at $265300^{\circ} \mathrm{C}$ should have destroyed the DFAA as suggested by Ito et al. (2006); no explanation 266 of this issue has been provided by Klevenz et al. (2010) but AA contamination during 267 sampling is plausible. The high concentrations of DFAA and DHAA in fluids from other non-ridge269 flank hydrothermal vent systems and hydrothermal influenced sediment listed in Table 5 
270 are attributed to large supplies of particulate organic matter-from biological production

271 or from organic-rich sediments - coupled to intensified acid hydrolysis due to low $\mathrm{pH}$

272 (down to $\mathrm{pH}=2$ ) and thermal decomposition (up to $104^{\circ} \mathrm{C}$ ), which often leads to

273 DFAA/DHAA ratios as high as 0.33-0.37 (Horiuchi et al., 2004; Svensson et al., 2004;

274 Lang et al., 2013). However, the oceanic basement fluids considered in this study were at

275 near-neutral $\mathrm{pH}(\sim 7.4)$ with a moderate temperature $\left(65^{\circ} \mathrm{C}\right)$ and very low particulate

276 organic carbon contents $(0.01-2 \mu \mathrm{mol} / \mathrm{L})$, which do not conspire to produce amino acids.

277 In addition, chemolithoautotrophy is more apparent in the comparing non-ridge-

278 hydrothermal systems (Kelley et al., 2005; Lang et al., 2013) than the ridge-flank system.

279 Some shallower vent sites and hydrothermal influenced sediment are located where

280 photoautotrophy is also a potential source for AAs (Hoaki et al., 1995; Wenzhöfer et al., $2812000)$.

282 The low AA concentrations in basement fluids, on the other hand, are similar to 283 those in seawater. The DFAA/DCAA is only $0.02-0.18$ in ridge flank basement fluids, 284 which is similar to those observed in near-shore and open ocean seawater (Lee and Bada, 285 1975; Coffin, 1989). In sum, unlike non-ridge-flank hydrothermal systems, heat 286 degradation and acid hydrolysis of particulate organic matter are likely not major controls 287 on the production of AAs in the ridge-flank subsurface hydrothermal systems. It is more 288 likely that the prevailing concentration of AAs in the basement are due to a combination 289 of seawater recharge, in situ production and transportation from overlying sediment, 290 heterotrophic consumption, and surface adsorption. 


\subsubsection{Input of amino acids from recharging seawater}

Basement fluids originate from deep seawater recharging through permeable unsedimented or thinly sedimented mid-ocean ridge or seamounts (Fisher et al., 2003;

296 Hutnak et al., 2006; Fisher and Wheat, 2010; Wheat et al., 2013). In the deep Pacific 297 Ocean (> $1000 \mathrm{~m}$ ), dissolved protein-like DOM, i.e., DHAA, is significantly older, by 298 three to four thousand years, than the amino acids in particulate organic matter and are 299 thus deduced to be less reactive to bacteria than younger particulate amino acids (Loh et 300 al., 2004). If such protein-like material remains unreactive in the basement, its presence 301 can explain the similarly low DHAA concentrations in the basement fluids and deep 302 seawater (Table 5). However, Loh et al. (2004) suggest that although protein-like 303 materials are significantly aged, they comprise the younger fractions of the DOM, and 304 thus are part of the more reactive components of deep seawater DOM. Because different 305 DHAA compositions are found in samples collected from different sites and times, 306 basement fluid DHAA — including those from recharging deep seawater — are deduced to 307 be reactive and/or derived from additional sources.

$308 \quad 4.2 .2$ In situ production in the basement

309 Biological activity has been inferred from traces of active chemolithoautotrophic 310 sulfate reduction within the ridge-flank basement environment, and it is supported by the

311 low $\delta{ }^{34} \mathrm{~S}$ values of pyrite from basaltic rock collected from site 1301 cores (Ono et al., 312 2012; Lever et al., 2013). Sulfate metabolism at site 1301A has also been inferred from 313 sulfate reduction rate measurements and phylogenetic analysis (Robador et al., 2015). 314 The carbon and hydrogen isotopic compositions of methane also suggest that microbial 
315 methanogenesis is responsible for the methane observed in CORKs 1362A and 1362B

316 basement fluids while isotopically heavy methane infers biological methane oxidation in

317 CORK 1301A (Lin et al., 2014). Based on carbon isotopic compositions, the high

318 molecular weight DOC in basement fluids is also thought to be synthesized by

319 chemosynthetic microbial communities in these fluids (McCarthy et al., 2010). Therefore,

320 it is very likely that in situ chemolithoautotrophic production of amino acids (free or

321 combined) also occurs. The basement fluids, despite their presumed low energy potential

322 (Boettger et al., 2013), are conducive to a wide variety of chemolithoautotrophic

323 metabolisms. For example, although energy is required for synthesizing AA at CORK

$3241301 \mathrm{~A}\left(\Delta G_{r}=4\right.$ to $17 \mathrm{~kJ} / \mathrm{mol} \mathrm{e}^{-}$, Figure 3$)$, energy can be released from

325 hydrogenotrophic methanogenesis $\left.\left(\Delta G_{r}=-5 \mathrm{~kJ} / \mathrm{mol} \mathrm{e}\right)^{-}\right)$, hydrogenotrophic sulfate

326 reduction $\left(\Delta G_{r}=-12 \mathrm{~kJ} / \mathrm{mol} \mathrm{e}^{-}\right)$or hydrogenotrophic iron reduction $\left(\Delta G_{r}=-48 \mathrm{~kJ} / \mathrm{mol} \mathrm{e}^{-}\right)$

327 at CORK 1301A (Boettger et al., 2013). Due to much higher concentrations of sulfate

$328(18.8 \mathrm{mM})$, bicarbonate $(359 \mu \mathrm{M})$, and hydrogen $(0.05-1.1 \mu \mathrm{M})$ relative to AAs (few $\mathrm{nM}$ ),

329 inorganic substrates in basement fluids can provide sufficient energy for microorganisms

330 such as methanogens and sulfate reducers to make all of the amino acids observed in the

331 basement environment.

332 Thermodynamic calculations also demonstrate that putative microbes living near the 333 sites with higher hydrogen concentrations (such as CORK 1301A in 2010) have an 334 anabolic advantage over microbes living in other sites or other times (CORK 1362A or 335 CORK 1362B in 2011) because it costs them less energy to make AAs indicating when 336 there is more reducing power available (Figure 3). Temporal changes in hydrogen 337 concentration are explained by a fracture-controlled flow pattern (Sherwood Lollar et al., 
338 2006) while spatial variation is likely due to heterogeneity of basaltic basement (Lin et al.,

339 2014). The AA synthesis reactions from $\mathrm{HCO}_{3}{ }^{-}, \mathrm{NH}_{4}{ }^{+}, \mathrm{H}_{2}$, and $\mathrm{HS}^{-}$(Table 1) in the Juan

340 de Fuca basement fluids are endergonic (positive $\Delta G_{r}$ at the prevailing conditions,

341 vertical dashed lines in Figure 3); therefore, the abiotic production of AAs is not

342 favorable. In contrast, the synthesis of 8 out of the 14 protein-forming AAs is

343 thermodynamically favorable (exergonic) under hot $\left(100^{\circ} \mathrm{C}\right)$ and reducing deep

344 submarine hydrothermal fluid conditions (Amend and Shock, 1998), suggesting that

345 abiotic production may be a source of AAs in these hydrothermal systems (Shock, 1990;

346 Amend and Shock, 1998; Shock and Canovas, 2010). The results presented in Fig. 3 are

347 not surprising because the measured hydrogen concentrations in ridge-flank basement

348 fluids (0.05-1.1 $\mu \mathrm{M}$, Lin et al., 2012, Lin et al., 2014) are two orders of magnitude lower

349 than that $(\sim 340 \mu \mathrm{M})$ used in the thermodynamic calculations by Amend and Shock

350 (1998). As shown in Figure 3, higher hydrogen concentrations yield lower $\Delta G_{r}$ values,

351 indicating more favorable energetics for AAs synthesis. Results from thermodynamic

352 modeling also show that there is a large difference in the Gibbs energies required for the

353 synthesis of different AAs, mostly due to the difference in the molecular structures of

354 individual AAs. Although it may seem surprising that less energy is required to produce

355 larger aromatic AAs such as phenylalanine and tryptophan than to produce smaller AAs

356 such as glycine and serine per electron transferred, relatively more oxidized aromatic

357 organic molecules require less energy to make from inorganic precursors than more

358 reduced organic compounds when the carbon source is $\mathrm{HCO}_{3}{ }^{-}$(LaRowe and Van

359 Cappellen, 2011). 
Enhanced biological productivity in deep sediments at site 1301A has been observed

362 and was suggested to be supported by the supply of sulfate from the basement (Engelen

363 et al., 2008). Enhanced biological productivity accompanied by decomposition of

364 sedimentary particulate organic matter leads to DFAA concentrations in deep

365 sedimentary porewater two-to-three orders of magnitude higher and DHAA

366 concentrations 9-15 times higher than those in the ridge-flank basement fluids, 367 respectively (Table A6). Such a concentration gradient provides a force for AA 368 transportation from overlying sediment into the basement. Diffusional inputs of inorganic 369 substrates - including ammonium and alkalinity - from overlying deep sediment to the 3703.5 million year old basement on the eastern flank of Juan de Fuca ridge have long been 371 suggested (Elderfield et al., 1999; Wheat et al., 2000; Lin et al., 2012; Wheat et al., 2013).

372 A recent study indicated that deep sedimentary DOC depth-profiles on the eastern flank 373 of Juan de Fuca ridge also exhibit a diffusional trend with minimum concentrations near 374 the sediment-basement interface (Lin et al., in press). The fact that the lowest total 375 dissolved amino acid concentration found in the porewater extracted from the deepest 376 core sampled ( $222 \mathrm{~m}$ below seafloor and $9 \mathrm{~m}$ above basement-sediment interface) may 377 suggest that there is a diffusional loss for dissolved amino acids into the basement (Table 378 A6).

4.2.4 Heterotrophic consumption-inferred from amino-acid-based degradation indices

381 The microbial preference for DFAAs over DCAAs (Keil and Kirchman, 1991a; 382 Middelboe et al., 1995) provides an explanation for the low DFAA/DCAA ratios found in 383 basement fluids. In addition to this bias, heterotrophic microorganisms have been shown 
384 to preferentially remove and transform some AAs over others (Dauwe et al., 1999;

385 Tanaka et al., 2011). As a result, three independent AA-based indices were developed to 386 quantify the extent to which DOM has been modified during heterotrophic activity: 387 carbon-normalized amino yields; Degradation Index (DI); and non-protein-forming AA $388 \quad(\gamma$-aminobutyric acid $)$ percentages.

389 Carbon-normalized AA yield, which is defined as the percentage of organic carbon 390 comprised by DHAA, has been suggested as a sensitive indicator for the early stage of 391 diagenesis (Cowie and Hedges, 1994; Davis et al., 2009; Kaiser and Benner, 2009). This 392 index is based on observations that AAs are preferentially utilized during microbial 393 decomposition of marine organic matter (Lee et al., 2000; Amon et al., 2001; Lee et al., 394 2004). The carbon-normalized AA yields for the ridge-flank basement fluids (1.3-3.3\%) 395 are similar to or slightly higher than those for seawater DOC (0.25-1.8 \%, Druffel et al., 396 1992; Benner, 2002; Kaiser and Benner, 2009) but at the low end of those for previously 397 reported non-ridge-flank hydrothermal vent fluids (2-25\%, Table 5). High carbon398 normalized AA yields are often associated with high fractions of labile organic matter, 399 such as fresh plankton biomass (35\%, Kaiser and Benner, 2009) and fresh plankton DOM 400 (21\%, Davis et al, 2009). Thus, the high AA yields in the non-ridge-flank hydrothermal 401 vent fluids suggest that the DOM in these systems is freshly produced with minimum 402 alteration. In contrast, the very low AA yield in deep seawater is attributed to extensive 403 heterotrophic processing of DOM (Kaiser and Benner, 2009). The slightly higher AA 404 yields in basement fluids relative to those in deep seawater, in fact, also result from 405 normalizing similar AA concentrations to much more depleted total DOC concentrations 
406 (12 $\mu \mathrm{M}$, Lin et al. 2012) than bottom seawater $(36 \mu \mathrm{M})$, indicating that DOC is 407 preferentially removed over AAs in the basement.

Unlike carbon-normalized AA yields, which entirely rely on DHAA 409 concentrations, DI values (Section 3.2) are based on the DHAA composition of a sample 410 compared to reference materials (here, marine-algae-derived DOM and seawater DOM).

411 DI has been suggested to be a sensitive indicator for intermediate stages of diagenesis 412 (Davis et al., 2009). The calculated DI values (Figure 4) follow the general observation 413 that high and usually positive values of DI are associated with source organic matter 414 (fresh marine-algae DOM), while extensively degraded (deep seawater) DOM is 415 characterized by low and sometimes negative DI values (Amon et al., 2001; Yamashita 416 and Tanoue, 2003; Kaiser and Benner, 2009). The calculated DI values of DOM in the 417 basement fluids (- 1.6 to 1.6, Table 4 and Figure 4) are all lower than the DI value of 418 fresh algal-derived DOM (2.6), while the DI values for CORK 1362A-2011 samples $419(-1.2 \pm 0.04)$ and CORK 1301A-2011 samples $(-1.6 \pm 0.02)$ are even lower than that of 420 deep seawater (- 0.8). The low DI values suggest that basement fluids contain degraded 421 AAs.

422 Non-protein-forming AAs, $\gamma$-aminobutyric acid and $\beta$-alanine, are produced 423 from incomplete degradation (i.e., partial decarboxylation) of glutamic acid and aspartic 424 acid, respectively (Schroeder, 1975; Whelan, 1977; Lee and Cronin, 1982). In particular, $425 \gamma$-aminobutyric acid has been suggested to be a sensitive indicator for advanced DOM 426 diagenesis (Cowie and Hedges, 1994; Dauwe et al., 1999; Tanaka et al., 2011). Both $\gamma$ 427 aminobutyric acid (0.6-18 $\mathrm{nM})$ and $\beta$-alanine (0.6-1.1 $\mathrm{nM})$ are enriched in CORK 
428 1301A, 1362A, and 1362B samples collected in 2011 (Table 4), while $\gamma$-aminobutyric 429 acid and $\beta$-alanine are not detected $(<0.1 \mathrm{nM})$ in CORK 1301A-2009 and 2010 samples.

430 The systematic trends observed in plots of the mole percentage of glutamic acid versus $\gamma$ 431 aminobutyric acid (Figure 5a) support the notion that the degradation of glutamic acid is 432 accompanied by the accumulation of $\gamma$-aminobutyric acid, which is also observed in other 433 studies (Cowie and Hedges, 1994; Dauwe et al., 1999; Kaiser and Benner, 2009; Tanaka 434 et al., 2011).

435 Despite the large uncertainties, organic carbon-normalized AA yields, DI values, 436 and the $\gamma$-aminobutyric acid percentage all suggest that degradation states of DOM in 437 basement fluid samples changed with location and time (Figure 5). The DOM in CORK $438 \quad$ 1362A-2011 and CORK 1301A-2011 samples were extensively degraded while the DOM 439 in CORK 1362B-2011 samples were at the early to intermediate stage of degradation. 440 CORK 1301A-2009 and CORK 1301A-2010 samples may contain less degraded DOM 441 than seawater. The degraded DOM in the basement fluid samples suggests that 442 heterotrophic activity occurs throughout the fluid flow paths.

\subsubsection{Surface sorption}

AAs in basaltic aquifer are susceptible to surface sorption because fluids flowing 445 through basement interact with all of the minerals typically found in basalt. The degree to 446 which there are electrostatic interactions between mineral surfaces and amino acids 447 depends upon the types of minerals present and the charge of the AAs. Although the 448 backbones of all AAs are zwitterionic in aqueous solutions, the functional groups (side449 chains) can be positively or negatively charged depending on the $\mathrm{pH}$ of the solution and 
450 the nature of the functional group (Table 1). As a result of the heterogeneity of AA

451 functional groups, some amino acids preferentially adsorb or desorb to mineral surfaces

452 (Henrichs and Sugai, 1993; Ding and Henrichs, 2002; Lambert, 2008). Based on

453 theoretical and empirical data, previous studies showed that clay minerals such as

454 kaolinite and smectite sorb positively charged basic amino acids (e.g., arginine) and tend

455 to repulse negatively charged acidic amino acids such as glutamic and aspartic acid at

456 neutral $\mathrm{pH}$ (Aufdenkampe et al., 2001; Tappin et al., 2010). That is, the relative

457 abundance of aspartic and glutamic acids and depletion of arginine in ridge-flank

458 basement fluids could be explained by electrostatic interactions with negatively surface-

459 charged secondary clay minerals (Marescotti et al., 2000) in the 3.5 million year old

460 basaltic rocks. In addition, some amino acids that are relatively hydrophobic, such as

461 phenylalanine, isoleucine and leucine, tend to sorb to particles (Aufdenkampe et al.,

462 2001), corresponding to lower abundances in basement fluids.

463 The effect of sorption can be visualized on a plot of scores of principal component

464 analysis (SPSS, unrotated factor solution) of AA compositions for basement fluids, deep

465 sediment porewater, sediment (Andersson et al., 2000), and North Pacific deep seawater

466 (Figure 6). The scores of principal component analysis distinctly separate aqueous

467 samples from sediment samples, indicating that DHAA compositions in aqueous samples

468 are very different from those in particulate sediment samples. Sorption can be used to

469 explain the enrichment of glutamic acid and aspartic acid in aqueous samples and the

470 enrichment of hydrophobic AAs in particulate sediment samples. In addition, because

471 peptides containing non-protein forming AAs have low surface affinity and are thus

472 preferentially retained in solution (Aufdenkampe et al., 2001), desorption from surfaces 
473 also enhances the enrichment of $\gamma$-aminobutyric acid and $\beta$-alanine in the fluid phase.

474 Because sorption enhances the retention of non-protein AA in solution, non-protein 475 forming AAs can no longer be interpreted solely as a diagenetic parameter when making 476 a comparison between dissolved and particulate phases. Nevertheless, the production of

477 non-protein-amino acids is from partial heterotrophic degradation of protein-forming 478 AAs in particulate or dissolved AA (Schroeder, 1975; Whelan, 1977; Lee and Cronin, 479 1982); the enrichment of NPAA is still linked to microbial activity (Aufdenkampe et al., 480 2001). Interestingly, CORK 1362A-2011, CORK 1362B-2011, CORK 1301A-2011, 481 1301A-2010 and 1301A-2009 scores from low (negative) to high (positive) values in 482 principle component two (y-axis in Figure 6), which mimics the change in their DI values 483 (Figure 5) and suggests that principle component two reflects the degradation states of 484 the samples. This notion is also supported by the observation that surface (young, less 485 degraded) sediment samples have more positive numbers than deep (old, more degraded) 486 samples (Figure 6). In sum, AA compositions in the basement fluid samples can be 487 explained by alteration processes including surface sorption, desorption and heterotrophic 488 alternation.

\subsection{Spatial and temporal variation of amino acids in the basement}

490 Spatial and temporal variations in amino acid concentrations and compositions are 491 likely a result of fluctuations in flow patterns and interactions between water, rock, and 492 microorganism. The change (43-89 $\mathrm{nM})$ is very small if we compare the values with non493 ridge-flank hydrothermal fluid AA concentrations (e.g. 0.736-2.3 $\mu \mathrm{M}$, Lang et al., 2013). 494 A similar range of DHAA concentrations was observed at the North Pacific time-series- 
495 station ALOHA $\left(22^{\circ} 45^{\prime} \mathrm{N}, 158^{\circ} \mathrm{W}\right)$, from $109 \mathrm{nM}$ in 1991 (McCarthy et al., 1996) to 60

$496 \mathrm{nM}$ in 2001 (Kaiser and Benner, 2009). The drop in DHAA concentration could be larger

497 because McCarthy et al. (1996) only analyzed the high-molecular-weight fraction (>

498 1000-Dalton) of the DOM while Kaiser and Benner (2009) analyzed total DOM.

499 Although the samples discussed in this study were collected using different methods,

500 from 60L-Tedlar bag sampler in 2009 and 2010 to $15-\mathrm{L}$ foil-lined, gamma irradiated bag

501 sampler in 2011, the sampler blanks do not show AA contamination that could account

502 for the change in AA concentrations. Disturbance from drilling and installment of

503 CORKs 1362A and 1362B during IODP Expedition 327 in October 2010 may be another

504 cause for the change in AA concentrations at site 1301A; however, we would expect

505 pumping of drilling fluids - mainly surface seawater-would introduce fresher DOC

506 instead of more refractory DOC observed in our 2011 samples. In addition, the changing

507 degradation status of DOM in basement fluids collected from site 1301A from 2009 to

5082011 also imply that (heterotrophic) microbial activity is temporally dynamic, which is

509 not inconsistent with a temporal variation in microbial community found at the same

510 study site (Jungbluth et al., 2013).

511 Spatial variation in AA concentrations and compositions in fluids from sites 1301A,

$5121362 \mathrm{~A}$ and $1362 \mathrm{~B}$ is also consistent with spatial variations in $\mathrm{H}_{2}$ and $\mathrm{CH}_{4}$ concentrations

513 (Lin et al., 2012; Lin et al., 2014). Interestingly, 1301A-2010 samples contained higher

514 amounts of amino acids and hydrogen relative to the 1362A-2011 samples (Table 3), but

515 the 1362A-2011 sample contained more degraded amino acids than 1301A-2010 sample.

516 A possible explanation for this observation is that the basement environment might be

517 changing from one that promotes autotrophy to one where heterotrophy is more favorable 
518 from $1301 \mathrm{~A}$ to $1362 \mathrm{~A}$. From an energetic perspective, the lower $\mathrm{H}_{2}$ concentrations at 519 1362A decrease to such low levels that autotrophic reactions such as methanogenesis 520 become endergonic (Lin et al., 2014).

\section{$521 \quad$ 5. Conclusions}

There is likely a complex, dynamic cycling on AAs in basement fluids supported

523 by the amounts of AAs present, DFAA/DHAA ratios, AA compositions, and AA-based

524 degradation indices. The concentrations of DFAA and DCAA in basement fluids are at

525 the low end of the range of values reported for non-ridge hydrothermal vent fluid samples,

526 largely attributed to conditions (moderate temperature, neutral $\mathrm{pH}$, low particulate

527 organic carbon input) unfavorable to dissolved AA production through heat degradation

528 and acid hydrolysis. DFAA and DCAA in basement fluids are likely a mixture of AAs

529 from recharging seawater, in situ microbial production, and input from overlying

530 sediment. The DHAA compositions are probably controlled by microbial consumption

531 and sorption to mineral surfaces. In situ biological synthesis of amino acids is supported

532 by the energy yield from chemolithotrophic reactions. In addition, three AA-based

533 degradation indices-carbon-normalized AA yields, Degradation Index, and $\gamma$ -

534 aminobutyric acid percentage-indicate that active heterotrophic organic matter

535 degradation is occurring in basement fluids. In terms of on-going research, the AA data

536 provide a guide for examining environmental genomic data from the same basement fluid

537 samples. For example, the presence of relatively abundant $\gamma$-aminobutyric acid (up to

$53818 \%$ ) indicates amino acid cycling during basement fluid flow that could be corroborated

539 by gene sequences responsible for this metabolic activity. Overall, the data presented in 540 this study provide a glimpse into the biogeochemistry of organic carbon dynamics in the 
541 deep subsurface and provide a foundation for exploring the microbiology of the oceanic 542 basement. 


\section{Acknowledgements}

544 This work was supported by NSF-Microbial Observatory Projects 06-04014 (to J. P. 545 Cowen) and 12-07880 (to J. P. Amend) and University of Hawaii Institute of 546 Astrobiology (UH-NAI, grant to J. P. Cowen). We would like to thank crews of $R / V$ 547 Atlantis, HOV Alvin \& ROV Jason for smooth cruises and submersible operations. We 548 also thank the Integrated Ocean Drilling Program for their support for Expeditions 301 549 and 327 as well as the design and installation of Circulation Obviation Retrofit Kit 550 observatories (CORKs) 1301A, 1362A, and 1362B. We thank Joseph Lichwa for his 551 tremendous support and assistance at our early stage of method development for AA 552 analysis. We also thank Dr. Ray Chittaranjan's generosity in providing an instrument for 553 the initial testing of the method for AA analysis. We thank Chih-Chiang Hsieh for his 554 help with the sample collection, Kathryn $\mathrm{Hu}$ and Natalie Hamada's assistance in 555 preparing lab ware needed for this study. We thank Dr. Mariko Hatta's critical comments 556 to help us improve the flow of thoughts of this manuscript. This is SOEST contribution X, 557 Center for Dark Energy Biosphere Investigations (C-DEBI) contribution Y and NASA 558 Astrobiology Institute — Life Underground (NAI-LU) contribution Z (to be assigned if 559 accepted for publication).

560 Conflict of interest: The authors state that there is no conflict of interest. 
562 Figure 1. (a) Bathymetry map showing Integrated Ocean Drilling Program (IODP) sites

563 U1301, U1362, and U1363 on the eastern flank of the Juan de Fuca Ridge. The insert

564 shows the location of the study sites, marked by an open square, relative to North

565 America. (b) Schematic depiction of the relative distances and penetration depths of 566 CORKs 1362A, 1362B, and 1301A.

567 Figure 2. Amino acid chromatograms of (a) AAH standards (Thermo Scientific Pierce) in 568 deep seawater at concentration between 10 to $250 \mathrm{nM}$, color-coded (from low to high 569 concentration): black, deep seawater from station ALOHA $\left(22^{\circ} 45^{\prime} \mathrm{N}, 158^{\circ} \mathrm{W}\right)$; brown, 10 $570 \mathrm{nM}$; dark blue, $25 \mathrm{nM}$; cyan, $50 \mathrm{nM}$; green, $75 \mathrm{nM}$; blue, $100 \mathrm{nM}$; and red, 250nM. (b) 571 CORK 1362A hydrolyzed sample. Total of fifteen protein forming amino acids are 572 shown in these chromatograms, including aspartic acid (ASP), glutamic acid (GLU), 573 serine (SER), histidine (HIS), glycine (GLY), arginine (ARG), threonine (THR), alanine 574 (ALA), tyrosine (TYR), methionine (MET), valine (VAL), phenylalanine (PHE), 575 isoleucine (ILE), leucine (LEU), and lysine (LYS). The peak of a non-protein forming 576 amino acid, $\gamma$-aminobutyric acid (GABA), is apparent in the CORK 1362A sample.

577 Figure 3. Energetics of the amino acid synthesis reactions listed in Table 1 at the in situ 578 temperature $\left(65^{\circ} \mathrm{C}\right)$ and pressure $(270$ bar $)$. The activities of amino acids, $\mathrm{H}_{2}, \mathrm{NH}_{4}{ }^{+}$, and 579 bicarbonate and $\mathrm{pH}$ used in these calculations are taken from Table 3. Black dashed lines 580 bracket the hydrogen activities from IODP holes 1362A, 1362B, and 1301A (Lin et al., 581 2014). Positive values of $\Delta G_{r}$ indicate that the reactions as written in Table 1 , and under 
582 the specified conditions, are not favored to progress to the right. The order of amino acids

583 listed in the legend follows the order of high to low energy demands from top to bottom.

584 Figure 4. Degradation Index of dissolved organic matter. More negative values indicate 585 greater degrees of degradation. Algal DOM values are from a 10-day degradation 586 experiment using fresh marine-algal-derived DOM as a substrate (Amon et al., 2001). 587 The amino acid compositions of the North Pacific surface seawater and $2000 \mathrm{~m}$ deep 588 seawater are from Kaiseer and Benner (2009).

589 Figure 5. Scatter plots of (a) glutamic acids (GLU) versus $\gamma$-aminobutyric acid (GABA); 590 (b) Degradation Index versus carbon-normalized amino acid yields (AA yield \%OC); (c) 591 Degradation Index versus $\gamma$-aminobutyric acid. Gray error bars are standard deviations (1 592 SD); no replicate samples were run for the CORK 1301A 2009 sample and the error bars 593 for this sample are the average deviations of all other samples.

594 Figure 6. Principal component analysis for comparison of amino acid compositions in the 595 Juan de Fuca eastern flank basement fluids, deep sediment porewater from IODP Site 596 1363D, sediment from ODP Site 1025 and 1028, which are $65 \mathrm{~km}$ and $55 \mathrm{~km}$ west597 northwest of Site 1301, respectively (Andersson et al., 2000), and North Pacific time598 series station ALOHA deep seawater (McCarthy et al., 1996; Kaiser and Benner, 2009). 599 Gray arrows denote amino acid loadings. 


\section{References}

Alford, S.E., Alt, J.C., Shanks Iii, W.C., 2011. Sulfur geochemistry and microbial sulfate reduction during low-temperature alteration of uplifted lower oceanic crust: Insights from ODP Hole 735B. Chem. Geol. 286, 185-195.

Alt, J.C., Shanks, W.C., 2011. Microbial sulfate reduction and the sulfur budget for a complete section of altered oceanic basalts, IODP Hole 1256D (eastern Pacific). Earth Planet. Sci. Lett. 310, 73-83.

Aluwihare, L.I., Meador, T., 2008. Chemical composition of marine dissolved organic nitrogen, in: Capone, D.G., Bronk, D.A., Mulholland, M.R., Carpenter, E.J. (Eds.), Nitrogen in the marine environment. San Diego, CA, USA: Academic Press, pp. 95-140.

Amend, J.P., Helgeson, H.C., 1997. Calculation of the standard molal thermodynamic properties of aqueous biomolecules at elevated temperatures and pressures Part $1 \mathrm{~L}-\alpha$-Amino acids. Journal of the Chemical Society, Faraday Transactions 93, 1927-1941.

Amend, J.P., Shock, E.L., 1998. Energetics of amino acid synthesis in hydrothermal ecosystems. Science 281, 1659-1662.

Amon, R.M., Fitznar, H.-P., Benner, R., 2001. Linkages among the bioreactivity, chemical composition, and diagenetic state of marine dissolved organic matter. Limnol. Oceanogr. 46, 287-297.

Andersson, E., Simoneit, B.R.T., Holm, N.G., 2000. Amino acid abundances and stereochemistry in hydrothermally altered sediments from the Juan de Fuca Ridge, northeastern Pacific Ocean. Applied Geochemistry 15, 1169-1190.

Aufdenkampe, A.K., Hedges, J.I., Richey, J.E., Krusche, A.V., Llerena, C.A., 2001. Sorptive fractionation of dissolved organic nitrogen and amino acids onto fine sediments within the Amazon Basin. Limnol. Oceanogr. 46, 1921-1935.

Bach, W., Edwards, K.J., 2003. Iron and sulfide oxidation within the basaltic ocean crust: Implications for chemolithoautotrophic microbial biomass production. Geochim. Cosmochim. Acta 67, 3871-3887.

Benner, R., 2002. Chemical composition and reactivity, in: Hansell, D.A.C.C. (Ed.), Biogeochemistry of marine dissolved organic matter. Elsevier, pp. 59-90.

Boettger, J., Lin, H.-T., Cowen, J.P., Henstscher, M., Amend, J.P., 2013. Energy yields from chemolithotrophic metabolisms in igneous basement of the Juan de Fuca ridge flank system. Chem. Geol. 337-338, 11-19.

Coffin, R.B., 1989. Bacterial uptake of dissolved free and combined amino acids in estuarine waters. Limnol. Oceanogr., 531-542.

Cowen, J.P., Copson, D.A., Jolly, J., Hsieh, C.-C., Lin, H.-T., Glazer, B.T., Wheat, C.G., 2012. Advanced instrument system for real-time and time-series microbial geochemical sampling of the deep (basaltic) crustal biosphere. Deep-Sea Res. PT I 61, 43-56.

Cowen, J.P., Giovannoni, S.J., Kenig, F., Johnson, H.P., Butterfield, D., Rappe, M.S., Hutnak, M., Lam, P., 2003. Fluids from aging ocean crust that support microbial life. Science 299, 120-123.

Cowie, G.L., Hedges, J.I., 1992. Sources and Reactivities of Amino-Acids in a Coastal Marine-Environment. Limnol. Oceanogr. 37, 703-724. 
Cowie, G.L., Hedges, J.I., 1994. Biochemical indicators of diagenetic alteration in natural organic matter mixtures.

Crawford, C.C., Hobbie, J., Webb, K., 1974. The utilization of dissolved free amino acids by estuarine microorganisms. Ecology, 551-563.

Dauwe, B., Middelburg, J.J., Herman, P.M.J., Heip, C.H.R., 1999. Linking diagenetic alteration of amino acids and bulk organic matter reactivity. Limnol. Oceanogr. 44, 1809-1814.

Davis, J., Benner, R., 2007. Quantitative estimates of labile and semi-labile dissolved organic carbon in the western Arctic Ocean: A molecular approach. Limnol. Oceanogr. 52, 2434-2444.

Davis, J., Kaiser, K., Benner, R., 2009. Amino acid and amino sugar yields and compositions as indicators of dissolved organic matter diagenesis. Organic Geochemistry 40, 343-352.

Dick, J., LaRowe, D., Helgeson, H., 2006. Temperature, pressure, and electrochemical constraints on protein speciation: Group additivity calculation of the standard molal thermodynamic properties of ionized unfolded proteins. Biogeosciences 3, 311-336.

Ding, X., Henrichs, S.M., 2002. Adsorption and desorption of proteins and polyamino acids by clay minerals and marine sediments. Mar. Chem. 77, 225-237.

Dirmeier, R., Keller, M., Hafenbradl, D., Braun, F.-J., Rachel, R., Burggraf, S., Stetter, K.O., 1998. Thermococcus acidaminovorans sp. nov., a new hyperthermophilic alkalophilic archaeon growing on amino acids. Extremophiles 2, 109-114.

Druffel, E.R.M., Williams, P.M., Bauer, J.E., Ertel, J.R., 1992. Cycling of dissolved and particulate organic-matter in the open ocean. J. Geophys. Res.-Oceans 97, 1563915659.

Elderfield, H., Wheat, C.G., Mottl, M.J., Monnin, C., Spiro, B., 1999. Fluid and geochemical transport through oceanic crust: a transect across the eastern flank of the Juan de Fuca Ridge. Earth Planet. Sci. Lett. 172, 151-165.

Engelen, B., Ziegelmueller, K., Wolf, L., Kopke, B., Gittel, A., Cypionka, H., Treude, T., Nakagawa, S., Inagaki, F., Lever, M.A., Steinsbu, B.O., 2008. Fluids from the oceanic crust support microbial activities within the deep biosphere. Geomicrobiol. J. 25, 56-66.

Expedition 327 Scientists, 2010. Juan de Fuca Ridge-flank hydrogeology: the hydrogeologic architecture of basaltic oceanic crust: compartmentalization, anisotropy, microbiology, and crustal-scale properties on the eastern flank of Juan de Fuca Ridge, eastern Pacific Ocean. IODP Prel. Rept. 327.

Fisher, A.T., 2005. Marine hydrogeology: recent accomplishments and future opportunities. Hydrogeol. J. 13, 69-97.

Fisher, A.T., Davis, E.E., Hutnak, M., Spiess, V., Zuhlsdorff, L., Cherkaoui, A., Christiansen, L., Edwards, K., Macdonald, R., Villinger, H., Mottl, M.J., Wheat, C.G., Becker, K., 2003. Hydrothermal recharge and discharge across $50 \mathrm{~km}$ guided by seamounts on a young ridge flank. Nature 421, 618-621.

Fisher, A.T., Wheat, C.G., 2010. Seamounts as conduits for massive fluid, heat, and solute fluxes on ridge flanks. Oceanography 23, 74.

Fisk, M.R., Giovannoni, S.J., Thorseth, I.H., 1998. Alteration of oceanic volcanic glass: Textural evidence of microbial activity. Science 281, 978-980. 
Fuhrman, J., 1987. Close coupling between release and uptake of dissolved free amino acids in seawater studied by an isotope dilution approach. Mar. Ecol. Prog. Ser 37, 45-52.

Furnes, H., Dilek, Y., Muehlenbachs, K., Banerjee, N.R., 2006. Tectonic control of bioalteration in modern and ancient oceanic crust as evidenced by carbon isotopes. Isl. Arc 15, 143-155.

Giovannoni, S.J., Fisk, M.R., Mullins, T.D., Furnes, H., 1996. Genetic evidence for endolithic microbial life colonizing basaltic glass/seawater interfaces. Proc. Ocean Drill. Program Sci. Results 148, 207-214.

Grasshoff, K., Ehrhardt, M., Kremling, K., Almgren, T., 1999. Methods of seawater analysis.

Haberstroh, P., Karl, D., 1989. Dissolved free amino acids in hydrothermal vent habitats of the Guaymas Basin. Geochim. Cosmochim. Acta 53, 2937-2945.

Hansell, D.A., Carlson, C.A., Repeta, D.J., Schlitzer, R., 2009. Dissolved organic matter in the ocean: a controversy stimulates new insights. Oceanography 22, 202-211.

Hecky, R.E., Mopper, K., Kilham, P., Degens, E.T., 1973. The amino acid and sugar composition of diatom cell-walls. Marine Biology 19, 323-331.

Heeschen, K.U., Tréhu, A.M., Collier, R.W., Suess, E., Rehder, G., 2003. Distribution and height of methane bubble plumes on the Cascadia Margin characterized by acoustic imaging. Geophys. Res. Lett. 30.

Helgeson, H.C., 1969. Thermodynamics of hydrothermal systems at elevated temperatures and pressures. Am. J. Sci. 267, 729-804.

Helgeson, H.C., Kirkham, D.H., Flowers, G.C., 1981. Theoretical prediction of the thermodynamic behavior of aqueous electrolytes by high pressures and temperatures; IV, Calculation of activity coefficients, osmotic coefficients, and apparent molal and standard and relative partial molal properties to 600 degrees $\mathrm{C}$ and 5kb. Am. J. Sci. 281, 1249-1516.

Henrichs, S.M., Sugai, S.F., 1993. Adsorption of amino acids and glucose by sediments of Resurrection Bay, Alaska, USA: Functional group effects. Geochim. Cosmochim. Acta 57, 823-835.

Hoaki, T., Nishijima, M., Kato, M., Adachi, K., Mizobuchi, S., Hanzawa, N., Maruyama, T., 1994. Growth requirements of hyperthermophilic sulfur-dependent heterotrophic archaea isolated from a shallow submarine geothermal system with reference to their essential amino acids. Appl. Environ. Microbiol. 60, 2898-2904.

Hoaki, T., Nishijima, M., Miyashita, H., Maruyama, T., 1995. Dense Community of Hyperthermophilic Sulfur-Dependent Heterotrophs in a Geothermally Heated Shallow Submarine Biotope near Kodakara-Jima Island, Kagoshima, Japan. Appl. Environ. Microbiol. 61, 1931-1937.

Hoaki, T., Wirsen, C.O., Hanzawa, S., Maruyama, T., Jannasch, H.W., 1993. Amino acid requirements of two hyperthermophilic archaeal isolates from deep-sea vents, Desulfurococcus strain SY and Pyrococcus strain GB-D. Appl. Environ. Microbiol. 59, 610-613.

Horiuchi, T., Takano, Y., Ishibashi, J.-i., Marumo, K., Urabe, T., Kobayashi, K., 2004. Amino acids in water samples from deep sea hydrothermal vents at Suiyo Seamount, Izu-Bonin Arc, Pacific Ocean. Organic Geochemistry 35, 1121-1128. 
Huber, J.A., Johnson, H.P., Butterfield, D.A., Baross, J.A., 2006. Microbial life in ridge flank crustal fluids. Environ. Microbiol. 8, 88-99.

Hutnak, M., Fisher, A.T., Zuhlsdorff, L., Spiess, V., Stauffer, P.H., Gable, C.W., 2006. Hydrothermal recharge and discharge guided by basement outcrops on 0.7-3.6 Ma seafloor east of the Juan de Fuca Ridge: Observations and numerical models. Geochem. Geophys. Geosyst. 7.

Ito, M., Gupta, L.P., Masuda, H., Kawahata, H., 2006. Thermal stability of amino acids in seafloor sediment in aqueous solution at high temperature. Organic Geochemistry 37, 177-188.

Jannasch, H.W., Wirsen, C.O., Molyneaux, S.J., Langworthy, T.A., 1988. Extremely thermophilic fermentative archaebacteria of the genus Desulfurococcus from deep-sea hydrothermal vents. Appl. Environ. Microbiol. 54, 1203-1209.

Johnson, H.P., Pruis, M.J., 2003. Fluxes of fluid and heat from the oceanic crustal reservoir. Earth Planet. Sci. Lett. 216, 565-574.

Johnson, J.W., Oelkers, E.H., Helgeson, H.C., 1992. SUPCRT92: A software package for calculating the standard molal thermodynamic properties of minerals, gases, aqueous species, and reactions from 1 to 5000 bar and 0 to 1000 C. Computers \& Geosciences 18, 899-947.

Jungbluth, S.P., Grote, J., Lin, H.-T., Cowen, J.P., Rappé, M.S., 2013. Microbial diversity within basement fluids of the sediment-buried Juan de Fuca Ridge flank. ISME Journal 7, 161-172.

Kaiser, K., Benner, R., 2008. Major bacterial contribution to the ocean reservoir of detrital organic carbon and nitrogen. Limnol. Oceanogr. 53, 99.

Kaiser, K., Benner, R., 2009. Biochemical composition and size distribution of organic matter at the Pacific and Atlantic time-series stations. Mar. Chem. 113, 63-77.

Kawasaki, N., Benner, R., 2006. Bacterial release of dissolved organic matter during cell growth and decline: Molecular origin and composition. Limnol. Oceanogr. 51, 2170-2180.

Keil, R.G., Kirchman, D.L., 1991a. Contribution of dissolved free amino acids and ammonium to the nitrogen requirements of heterotrophic bacterioplankton. Mar. Ecol. Prog. Ser 73, 1-10.

Keil, R.G., Kirchman, D.L., 1991b. Dissolved combined amino acids in marine waters as determined by a vapor-phase hydrolysis method. Mar. Chem. 33, 243-259.

Kelley, D.S., Karson, J.A., Fruh-Green, G.L., Yoerger, D.R., Shank, T.M., Butterfield, D.A., Hayes, J.M., Schrenk, M.O., Olson, E.J., Proskurowski, G., Jakuba, M., Bradley, A., Larson, B., Ludwig, K., Glickson, D., Buckman, K., Bradley, A.S., Brazelton, W.J., Roe, K., Elend, M.J., Delacour, A., Bernasconi, S.M., Lilley, M.D., Baross, J.A., Summons, R.T., Sylva, S.P., 2005. A serpentinite-hosted ecosystem: The lost city hydrothermal field. Science 307, 1428-1434.

Klevenz, V., Sumoondur, A., Ostertag-Henning, C., Koschinsky, A., 2010. Concentrations and distributions of dissolved amino acids in fluids from MidAtlantic Ridge hydrothermal vents. Geochemical Journal 44, 387.

Lambert, J.-F., 2008. Adsorption and polymerization of amino acids on mineral surfaces: a review. Origins of Life and Evolution of Biospheres 38, 211-242.

Lang, S., Früh-Green, G., Bernasconi, S., Butterfield, D., 2013. Sources of organic nitrogen at the serpentinite-hosted Lost City hydrothermal field. Geobiology. 
Lang, S.Q., Butterfield, D.A., Lilley, M.D., Johnson, H.P., Hedges, J.I., 2006. Dissolved organic carbon in ridge-axis and ridge-flank hydrothermal systems. Geochim. Cosmochim. Acta 70, 3830-3842.

LaRowe, D.E., Dick, J.M., 2012. Calculation of the standard molal thermodynamic properties of crystalline peptides. Geochim. Cosmochim. Acta 80, 70-91.

LaRowe, D.E., Van Cappellen, P., 2011. Degradation of natural organic matter: A thermodynamic analysis. Geochim. Cosmochim. Acta 75, 2030-2042.

Lee, C., Bada, J.L., 1975. Amino acids in equatorial Pacific Ocean water. Earth Planet. Sci. Lett. 26, 61-68.

Lee, C., Cronin, C., 1982. The vertical flux of particulate organic nitrogen in the sea: decomposition of amino acids in the Peru upwelling area and the equatorial Atlantic. Journal of Marine Research 40, 227-251.

Lee, C., Wakeham, S., Arnosti, C., 2004. Particulate organic matter in the sea: The composition conundrum. AMBIO: A Journal of the Human Environment 33, 565575.

Lee, C., Wakeham, S.G., I Hedges, J., 2000. Composition and flux of particulate amino acids and chloropigments in equatorial Pacific seawater and sediments. Deep-Sea Res. PT I 47, 1535-1568.

Lever, M., Rouxel, O., Alt, J.C., Shimizu, N., Ono, S., Coggon, R.M., Shanks III, W.C., Lapham, L., Elvert, M., Prieto-Mollar, X., Hinrichs, K.U., Inagaki, F., Teske, A., 2013. Evidence for microbial carbon and sulfur cycling in deeply buried ridge flank basalt. Science 339, 1305-1308.

Lin, H.-T., Cowen, J.P., Olson, E.J., Amend, J.P., Lilley, M.D., 2012. Inorganic chemistry, gas compositions and dissolved organic carbon in fluids from sedimented young basaltic crust on the Juan de Fuca Ridge flanks. Geochim. Cosmochim. Acta 85, 213-227.

Lin, H.-T., Cowen, J.P., Olson, E.J., Lilley, M.D., Jungbluth, S.P., Rappé, M.S., Wilson, S.T., 2014. Dissolved hydrogen and methane in the oceanic basaltic biosphere. Earth Planet. Sci. Lett. 405, 62-73.

Lin, H.-T., Hsieh, C.-C., Cowen, J.P., Rappé, M.S., in press. Data Report: Dissolved and particulate organic carbon in the deep sediments of U1363 near Grizzly Bare Seamount. Proc. IODP 327.

Loh, A.N., Bauer, J.E., Druffel, E.R., 2004. Variable ageing and storage of dissolved organic components in the open ocean. Nature 430, 877-881.

Marescotti, P., Vanko, D.A., Cabella, R., 2000. From oxidizing to reducing alteration: Mineralogical variations in pillow basalts from the east flank, Juan de Fuca Ridge. Proc. Ocean Drill. Program, Sci. Results 168, 119-136.

McCarthy, M., Hedges, J., Benner, R., 1996. Major biochemical composition of dissolved high molecular weight organic matter in seawater. Mar. Chem. 55, 281297.

McCarthy, M.D., Beaupre, S.R., Walker, B.D., Voparil, I., Guilderson, T.P., Druffel, E.R.M., 2010. Chemosynthetic origin of C-14-depleted dissolved organic matter in a ridge-flank hydrothermal system. Nat. Geosci. 4, 32-36.

Middelboe, M., Borch, N.H., Kirchman, D.L., 1995. Bacterial utilization of dissolved free amino acids, dissolved combined amino acids and ammonium in the 
Delaware Bay estuary: Effects of carbon and nitrogen limitation. Marine EcologyProgress Series 128, 109-120.

Mottl, M.J., 2003. Partitioning of energy and mass fluxes between mid-ocean ridge axes and flanks at high and low temperature, in: Halbach, P.E., Tunnicliffe, V., Hein, J.R. (Eds.), Energy and Mass Transfer in Marine Hydrothermal Systems. Dahlem University Press, Berlin, pp. 271-286.

Ono, S., Keller, N.S., Rouxel, O., Alt, J.C., 2012. Sulfur-33 constraints on the origin of secondary pyrite in altered oceanic basement. Geochim. Cosmochim. Acta.

Ouverney, C.C., Fuhrman, J.A., 2000. Marine planktonic Archaea take up amino acids. Appl. Environ. Microbiol. 66, 4829-+.

Pledger, R.J., Baross, J.A., 1991. Preliminary description and nutritional characterization of a chemoorganotrophic archaeobacterium growing at temperatures of up to $110^{\circ}$ isolated from a submarine hydrothermal vent environment. Journal of general microbiology 137, 203-211.

Robador, A., Jungbluth, S.P., LaRowe, D.E., Bowers, R.M., Rappé, M.S., Amend, J.P., Cowen, J.P., 2015. Activity and phylogenetic diversity of sulfate-reducing microorganisms in low-temperature subsurface fluids within the upper oceanic crust. Frontiers in Microbiology 5, 748.

Rouxel, O., Ono, S., Alt, J., Rumble, D., Ludden, J., 2008. Sulfur isotope evidence for microbial sulfate reduction in altered oceanic basalts at ODP Site 801. Earth Planet. Sci. Lett. 268, 110-123.

Schroeder, R.A., 1975. Absence of $\beta$-alanine and $\gamma$-aminobutyric acid in cleaned foraminiferal shells: Implications for use as a chemical criterion to indicate removal of non-indigenous amino acid contaminants. Earth Planet. Sci. Lett. 25, 274-278.

Schulte, M.D., Shock, E.L., Wood, R.H., 2001. The temperature dependence of the standard-state thermodynamic properties of aqueous nonelectrolytes. Geochim. Cosmochim. Acta 65, 3919-3930.

Sherwood Lollar, B., Lacrampe-Couloume, G., Slater, G.F., Ward, J., Moser, D.P., Gihring, T.M., Lin, L.H., Onstott, T.C., 2006. Unravelling abiogenic and biogenic sources of methane in the Earth's deep subsurface. Chem. Geol. 226, 328-339.

Shipboard Scientific Party, 2004. Juan de Fuca hydrogeology: The hydrogeologic architecture of basaltic oceanic crust: compartmentalization, anisotropy, microbiology, and crustal-scale properties on the eastern flank of Juan de Fuca Ridge, eastern Pacific Ocean. IODP Prel. Rept. 301.

Shock, E., Canovas, P., 2010. The potential for abiotic organic synthesis and biosynthesis at seafloor hydrothermal systems. Geofluids 10, 161-192.

Shock, E.L., 1990. Geochemical Constraints on the Origin of Organic-Compounds in Hydrothermal Systems. Origins Life Evol. B. 20, 331-367.

Shock, E.L., Helgeson, H.C., 1988. Calculation of the thermodynamic and transport properties of aqueous species at high pressures and temperatures: Correlation algorithms for ionic species and equation of state predictions to $5 \mathrm{~kb}$ and $1000^{\circ} \mathrm{C}$. Geochim. Cosmochim. Acta 52, 2009-2036.

Shock, E.L., Helgeson, H.C., Sverjensky, D.A., 1989. Calculation of the thermodynamic and transport properties of aqueous species at high pressures and temperatures: 
Standard partial molal properties of inorganic neutral species. Geochim. Cosmochim. Acta 53, 2157-2183.

Shock, E.L., Oelkers, E.H., Johnson, J.W., Sverjensky, D.A., Helgeson, H.C., 1992. Calculation of the thermodynamic properties of aqueous species at high pressures and temperatures. Effective electrostatic radii, dissociation constants and standard partial molal properties to $1000 \mathrm{C}$ and 5 kbar. Journal of the Chemical Society, Faraday Transactions 88, 803-826.

Siegenthaler, U., Sarmiento, J.L., 1993. Atmospheric carbon-dioxide and the ocean. Nature 365, 119-125.

Svensson, E., Skoog, A., Amend, J.P., 2004. Concentration and distribution of dissolved amino acids in a shallow hydrothermal system, Vulcano Island (Italy). Organic Geochemistry 35, 1001-1014.

Takano, Y., Horiuchi, T., Kobayashi, K., Marumo, K., Urabe, T., 2003. Large enantiomeric excesses of L-form amino acids in deep-sea hydrothermal sub-vent of $156^{\circ} \mathrm{C}$ fluids at the Suiyo Seamount, Izu-Bonin Arc, Pacific ocean. Chemistry letters 32, 970-971.

Tanaka, Y., Miyajima, T., Watanabe, A., Nadaoka, K., Yamamoto, T., Ogawa, H., 2011. Distribution of dissolved organic carbon and nitrogen in a coral reef. Coral Reefs 30, 533-541.

Tanger, J.C., Helgeson, H.C., 1988. Calculation of the thermodynamic and transport properties of aqueous species at high pressures and temperatures; revised equations of state for the standard partial molal properties of ions and electrolytes. Am. J. Sci. 288, 19-98.

Tappin, A., Millward, G., Fitzsimons, M., 2010. Particle-water interactions of organic nitrogen in turbid estuaries. Mar. Chem. 122, 28-38.

Wenzhöfer, F., Holby, O., Glud, R.N., Nielsen, H.K., Gundersen, J.K., 2000. In situ microsensor studies of a shallow water hydrothermal vent at Milos, Greece. Mar. Chem. 69, 43-54.

Wheat, C.G., Elderfield, H., Mottl, M.J., Monnins, C., 2000. Chemical composition of basement fluids within an oceanic ridge flank: Implications for along-strike and across-strike hydrothermal circulation. J. Geophys. Res. 105, 13437-13447.

Wheat, C.G., Hulme, S.M., Fisher, A.T., Orcutt, B.N., Becker, K., 2013. Seawater recharge into oceanic crust: IODP Exp 327 Site U1363 Grizzly Bare outcrop. Geochem. Geophys. Geosyst. 14, 1957-1972.

Wheat, C.G., Jannasch, H.W., Fisher, A.T., Becker, K., Sharkey, J., Hulme, S., 2010. Subseafloor seawater-basalt-microbe reactions: Continuous sampling of borehole fluids in a ridge flank environment. Geochem. Geophy. Geosy. 11, 1-18.

Wheat, C.G., McManus, J., Mottl, M.J., Giambalvo, E., 2003. Oceanic phosphorus imbalance: Magnitude of the mid-ocean ridge flank hydrothermal sink. Geophys. Res. Lett 30, 1895.

Wheeler, P.A., Kirchman, D.L., 1986. Utilization of inorganic and organic nitrogen by bacteria in marine systems. Limnol. Oceanogr., 998-1009.

Whelan, J.K., 1977. Amino acids in a surface sediment core of the Atlantic abyssal plain. Geochim. Cosmochim. Acta 41, 803-810.

Yamashita, Y., Tanoue, E., 2003. Distribution and alteration of amino acids in bulk DOM along a transect from bay to oceanic waters. Mar. Chem. 82, 145-160. 
Table 1. Net reactions of amino acid synthesis. $\log \mathrm{K}$ is the logarithm of equilibrium constant $(\mathrm{K})$ for the indicated reactions at $65^{\circ} \mathrm{C}, 270 \mathrm{bar}$ and $\mathrm{pH}=7.4$.

\begin{tabular}{|c|c|c|c|c|c|c|c|c|c|c|c|c|c|c|}
\hline \multirow{3}{*}{$\begin{array}{l}\text { Properties } \\
\text { Negatively } \\
\text { charged } \\
\text { (acidic) } \\
\text { side-chain }\end{array}$} & \multirow{2}{*}{$\begin{array}{l}\text { Amino acids } \\
\text { Aspartate }\end{array}$} & \multicolumn{12}{|c|}{ Net amino acid synthesis reactions } & \multirow{2}{*}{$\begin{array}{r}\log K \\
45.97\end{array}$} \\
\hline & & $4 \mathrm{HCO}_{3}^{-}$ & + & $2 \mathrm{H}^{+}$ & + & $\mathrm{NH}_{4}^{+}$ & + & $6 \mathrm{H}_{2}$ & & $\rightarrow$ & $\mathrm{C}_{4} \mathrm{H}_{7} \mathrm{NO}_{4}^{-}$ & + & $9 \mathrm{H}_{2} \mathrm{O}$ & \\
\hline & Glutamate & $5 \mathrm{HCO}_{3}^{-}$ & + & $3 \mathrm{H}^{+}$ & + & $\mathrm{NH}_{4}^{+}$ & + & $9 \mathrm{H}_{2}$ & & $\rightarrow$ & $\mathrm{C}_{5} \mathrm{H}_{8} \mathrm{NO}_{4}^{-}$ & + & $11 \mathrm{H}_{2} \mathrm{O}$ & 69.39 \\
\hline \multirow{5}{*}{$\begin{array}{l}\text { Nonpolar, } \\
\text { aliphatic } \\
\text { side-chain }\end{array}$} & Alanine & $3 \mathrm{HCO}_{3}^{-}$ & + & $2 \mathrm{H}^{+}$ & + & $\mathrm{NH}_{4}^{+}$ & + & $6 \mathrm{H}_{2}$ & & $\rightarrow$ & $\mathrm{C}_{3} \mathrm{H}_{7} \mathrm{NO}_{2}$ & + & $7 \mathrm{H}_{2} \mathrm{O}$ & 45.00 \\
\hline & Glycine & $2 \mathrm{HCO}_{3}^{-}$ & + & $1 \mathrm{H}^{+}$ & + & $\mathrm{NH}_{4}^{+}$ & + & $3 \mathrm{H}_{2}$ & & $\rightarrow$ & $\mathrm{C}_{2} \mathrm{H}_{5} \mathrm{NO}_{2}$ & + & $4 \mathrm{H}_{2} \mathrm{O}$ & 19.07 \\
\hline & Isoleucine & $6 \mathrm{HCO}_{3}^{-}$ & + & $5 \mathrm{H}^{+}$ & + & $\mathrm{NH}_{4}^{+}$ & + & $15 \mathrm{H}_{2}$ & & $\rightarrow$ & $\mathrm{C}_{6} \mathrm{H}_{13} \mathrm{NO}_{2}$ & + & $16 \mathrm{H}_{2} \mathrm{O}$ & 123.23 \\
\hline & Leucine & $6 \mathrm{HCO}_{3}^{-}$ & + & $5 \mathrm{H}^{+}$ & + & $\mathrm{NH}_{4}^{+}$ & + & $15 \mathrm{H}_{2}$ & & $\rightarrow$ & $\mathrm{C}_{6} \mathrm{H}_{13} \mathrm{NO}_{2}$ & + & $16 \mathrm{H}_{2} \mathrm{O}$ & 124.48 \\
\hline & Valine & $5 \mathrm{HCO}_{3}^{-}$ & + & $4 \mathrm{H}^{+}$ & + & $\mathrm{NH}_{4}^{+}$ & + & $12 \mathrm{H}_{2}$ & & $\rightarrow$ & $\mathrm{C}_{5} \mathrm{H}_{11} \mathrm{NO}_{2}$ & + & $13 \mathrm{H}_{2} \mathrm{O}$ & 97.92 \\
\hline \multirow{2}{*}{$\begin{array}{l}\text { Polar, } \\
\text { positively } \\
\text { charged } \\
\text { side-chain }\end{array}$} & Arginine & $6 \mathrm{HCO}_{3}^{-}$ & + & $3 \mathrm{H}^{+}$ & + & $4 \mathrm{NH}_{4}^{+}$ & + & $11 \mathrm{H}_{2}$ & & $\rightarrow$ & $\mathrm{C}_{6} \mathrm{H}_{15} \mathrm{~N}_{4} \mathrm{O}_{2}^{+}$ & + & $16 \mathrm{H}_{2} \mathrm{O}$ & 58.60 \\
\hline & Histidine $^{a}$ & $6 \mathrm{HCO}_{3}^{-}$ & + & $3 \mathrm{H}^{+}$ & + & $3 \mathrm{NH}_{4}^{+}$ & + & $10 \mathrm{H}_{2}$ & & $\rightarrow$ & $\mathrm{C}_{6} \mathrm{H}_{9} \mathrm{~N}_{3} \mathrm{O}_{2}$ & + & $16 \mathrm{H}_{2} \mathrm{O}$ & 63.83 \\
\hline \multirow{2}{*}{$\begin{array}{l}\text { Polar, } \\
\text { uncharged } \\
\text { side-chain }\end{array}$} & Serine & $3 \mathrm{HCO}_{3}^{-}$ & + & $2 \mathrm{H}^{+}$ & + & $\mathrm{NH}_{4}^{+}$ & + & $5 \mathrm{H}_{2}$ & & $\rightarrow$ & $\mathrm{C}_{3} \mathrm{H}_{7} \mathrm{NO}_{3}$ & + & $6 \mathrm{H}_{2} \mathrm{O}$ & 29.09 \\
\hline & Threonine & $4 \mathrm{HCO}_{3}^{-}$ & + & $3 \mathrm{H}^{+}$ & + & $\mathrm{NH}_{4}^{+}$ & + & $8 \mathrm{H}_{2}$ & & $\rightarrow$ & $\mathrm{C}_{4} \mathrm{H}_{9} \mathrm{NO}_{3}$ & + & $9 \mathrm{H}_{2} \mathrm{O}$ & 53.54 \\
\hline $\begin{array}{l}\text { Sulfur } \\
\text { containing }\end{array}$ & Methionine & $5 \mathrm{HCO}_{3}^{-}$ & + & $5 \mathrm{H}^{+}$ & + & $\mathrm{NH}_{4}^{+}$ & + & $11 \mathrm{H}_{2}$ & $+\mathrm{HS}^{-}$ & $\rightarrow$ & $\mathrm{C}_{5} \mathrm{H}_{11} \mathrm{NO}_{2} \mathrm{~S}$ & + & $13 \mathrm{H}_{2} \mathrm{O}$ & 92.00 \\
\hline \multirow{3}{*}{$\begin{array}{l}\text { Aromatic } \\
\text { side-chain }\end{array}$} & Phenylalanine & $9 \mathrm{HCO}_{3}^{-}$ & + & $8 \mathrm{H}^{+}$ & + & $\mathrm{NH}_{4}^{+}$ & + & $20 \mathrm{H}_{2}$ & & $\rightarrow$ & $\mathrm{C}_{9} \mathrm{H}_{10} \mathrm{NO}_{2}$ & + & $25 \mathrm{H}_{2} \mathrm{O}$ & 174.00 \\
\hline & Tryptophan & $11 \mathrm{HCO}_{3}^{-}$ & + & $9 \mathrm{H}^{+}$ & + & $2 \mathrm{NH}_{4}^{+}$ & + & $23 \mathrm{H}_{2}$ & & $\rightarrow$ & $\mathrm{C}_{11} \mathrm{H}_{12} \mathrm{~N}_{2} \mathrm{O}_{2}$ & + & $31 \mathrm{H}_{2} \mathrm{O}$ & 193.67 \\
\hline & Tyrosine & $9 \mathrm{HCO}_{3}^{-}$ & + & $8 \mathrm{H}^{+}$ & + & $\mathrm{NH}_{4}^{+}$ & + & $19 \mathrm{H}_{2}$ & & $\rightarrow$ & $\mathrm{C}_{9} \mathrm{H}_{11} \mathrm{NO}_{3}$ & + & $24 \mathrm{H}_{2} \mathrm{O}$ & 161.97 \\
\hline
\end{tabular}

a. Although histidine is likely uncharged at $\mathrm{pH} 7.4$, it has an aromatic imidazole side chain that dissociates near neutral $\mathrm{pH}$ and become positively charged. 
Table 2. Compositions of basement fluids collected from CORK 1362A, 1362B and 1301A. Numbers in parenthesis are uncertainties in reproducibility. Dash (-) indicate no data.

\begin{tabular}{|c|c|c|c|c|c|c|c|c|c|c|}
\hline \multicolumn{2}{|c|}{ Sample site } & \multirow{2}{*}{\multicolumn{2}{|c|}{$\begin{array}{l}\text { CORK } 1362 B^{a} \\
2011\end{array}$}} & \multirow{2}{*}{\multicolumn{2}{|c|}{$\begin{array}{l}\text { CORK 1362A }^{a} \\
2011\end{array}$}} & \multirow{2}{*}{\multicolumn{2}{|c|}{$\frac{\text { CORK 1301A }^{\mathrm{b}}}{2008-2011}$}} & \multirow{2}{*}{\multicolumn{2}{|c|}{$\begin{array}{c}\text { Bottom seawater } \\
2008-2010\end{array}$}} & \multirow[b]{3}{*}{$\begin{array}{l}\text { Analytical } \\
\text { uncertainty }\end{array}$} \\
\hline & & & & & & & & & & \\
\hline Variables $^{c}$ & unit & $\begin{array}{l}\mathrm{Mg} \\
\text { Corr. }\end{array}$ & $(n=9)$ & Mg Corr. & $(n=6)$ & $\begin{array}{l}\text { Mg } \\
\text { Corr. }\end{array}$ & $(n=12)$ & - & $(n=5)$ & \\
\hline Temperature & ${ }^{\circ} \mathrm{C}$ & $65^{d}$ & - & $65^{d}$ & - & 65 & - & 1.7 & - & - \\
\hline Pressure & bar & $270^{d}$ & - & $270^{d}$ & - & 270 & - & 270 & - & - \\
\hline pH & - & 7.3 & - & 7.5 & - & 7.4 & $(0.1)$ & 7.7 & $(0.1)$ & $(0.1)$ \\
\hline Magnesium & $\mathrm{mM}$ & 1.6 & - & 2.5 & - & 1.9 & - & 53.7 & $(0.3)$ & $(0.5)$ \\
\hline Calcium & $\mathrm{mM}$ & 55.9 & $(0.3)$ & 54.5 & $(0.1)$ & 55.0 & (1) & 10.4 & $(0.03)$ & $(0.2)$ \\
\hline Sulfate & $\mathrm{mM}$ & 18.8 & (0.1) & 18.8 & $(0.4)$ & 18.0 & $(0.3)$ & 28.4 & $(0.3)$ & $(0.3)$ \\
\hline Chloride & $\mathrm{mM}$ & 552 & (2) & 548 & (1) & 552 & (6) & 541 & (14) & $(5.4)$ \\
\hline Sodium & $\mathrm{mM}$ & 462 & (1) & 461 & (1) & 468 & (6) & 467 & (13) & (3) \\
\hline Potassium & $\mathrm{mM}$ & 6.4 & $(0.1)$ & 6.5 & $(0.1)$ & 6.2 & $(0.4)$ & 10.2 & $(0.3)$ & $(0.2)$ \\
\hline Alkalinity & $\mathrm{meq} / \mathrm{L}$ & 0.47 & $(0.01)$ & 0.58 & $(0.02)$ & 0.45 & $(0.04)$ & 2.48 & $(0.05)$ & $(0.02)$ \\
\hline Hydrogen & $\mu \mathrm{M}$ & 0.08 & $(0.03)$ & 0.05 & $(0.02)$ & 1.1 & $(1.2)$ & $0.0004^{e}$ & - & $(0.0002)$ \\
\hline Ammonium & $\mu \mathrm{M}$ & 101 & $(0.4)$ & 99 & (1.0) & 102 & (3.0) & $<0.05$ & - & $(0.1 \sim 2)$ \\
\hline Sulfide & $\mu \mathrm{M}$ & $0.17^{d}$ & - & $0.17^{d}$ & - & 0.17 & - & - & - & \\
\hline
\end{tabular}
a. This study and Lin et al. (2014)
b. Data from Lin et al. (2012)
c. All values are Mg corrected. See Lin et al. (2012) for details.
d. Data not available, using values for CORK 1301A fluids.
e. Data from Kelley et al. (1998) 
Table 3. Activities of chemical species used for thermodynamic calculations. The proton, bicarbonate and ammonium concentrations are the average of 1301A, 1362B and 1362A values. The amino acid concentrations are the value or the average value of detected dissolved free amino acids in the samples collected from Hole U 1301A, 1362B and 1362A in Table 3. The detection limits are used for the undetected free amino acids such as phenylalanine and leucine.

\begin{tabular}{|c|c|c|c|c|c|}
\hline Species & $\begin{array}{l}\text { Detection } \\
\text { limit }(\mu \mathrm{M}) \\
\end{array}$ & $\begin{array}{c}\text { Concentration } \\
(\mu \mathrm{M})\end{array}$ & $\begin{array}{c}\text { Activity } \\
\text { coefficient }\end{array}$ & Activity & $\log$ (Activity) \\
\hline $\mathrm{H}^{+}$ & N.A. & 0.051 & 0.80 & $4.1 \mathrm{E}-08$ & -7.4 \\
\hline $\mathrm{HCO}_{3}^{-}$ & 0.2 & 359 & 0.67 & $2.4 \mathrm{E}-04$ & -3.6 \\
\hline $\mathrm{NH}_{4}^{+}$ & 0.05 & 101 & 0.59 & $5.9 \mathrm{E}-05$ & -4.2 \\
\hline HS- & 0.15 & 0.17 & 0.64 & $1.1 \mathrm{E}-07$ & -7.0 \\
\hline $\mathrm{H}_{2 \_1301 \mathrm{~A}-2010^{a}}$ & 0.0002 & 1.1 & 1.13 & $1.2 \mathrm{E}-06$ & -5.9 \\
\hline $\mathrm{H}_{2 \_1362 \mathrm{~A}-2011^{b}}$ & 0.0002 & 0.05 & 1.13 & 5.7E-08 & -7.2 \\
\hline \multirow[t]{2}{*}{$\mathrm{H}_{2-1362 \mathrm{~B}-2011^{b}}$} & 0.0002 & 0.08 & 1.13 & $9.0 \mathrm{E}-08$ & -7.0 \\
\hline & $\begin{array}{l}\text { Detection } \\
\text { limit }(n M)\end{array}$ & $\begin{array}{l}\text { Concentration } \\
\text { (nM) }\end{array}$ & & & \\
\hline ASP & 0.2 & 1.1 & 0.66 & $6.9 \mathrm{E}-10$ & -9.2 \\
\hline GLU & 0.2 & 1.2 & 0.66 & $7.9 \mathrm{E}-10$ & -9.1 \\
\hline SER & 0.2 & 2.7 & 1.0 & 2.7E-09 & -8.6 \\
\hline HIS & 0.8 & 1.5 & 1.0 & $1.5 \mathrm{E}-09$ & -8.8 \\
\hline GLY & 0.8 & 2.3 & 1.0 & $2.3 \mathrm{E}-09$ & -8.6 \\
\hline THR & 0.3 & 0.3 & 1.0 & 2.7E-10 & -9.6 \\
\hline ARG & 0.2 & 1.0 & 0.66 & $6.6 \mathrm{E}-10$ & -9.2 \\
\hline ALA & 0.2 & 1.0 & 1.0 & $9.5 \mathrm{E}-10$ & -9.0 \\
\hline TYR & 0.2 & 0.4 & 1.0 & $3.5 \mathrm{E}-10$ & -9.5 \\
\hline MET & 0.2 & 1.1 & 1.0 & $1.1 \mathrm{E}-09$ & -9.0 \\
\hline VAL & 0.2 & 0.2 & 1.0 & $1.5 \mathrm{E}-10$ & -9.8 \\
\hline PHE & 0.2 & 0.2 & 1.0 & $2.1 \mathrm{E}-10$ & -9.7 \\
\hline ILE & 0.1 & 0.1 & 1.0 & $1.4 \mathrm{E}-10$ & -9.9 \\
\hline LEU & 0.2 & 0.2 & 1.0 & $1.9 \mathrm{E}-10$ & -9.7 \\
\hline
\end{tabular}

a. Data from Lin et al. 2012

b. Data from Lin et al. 2014 
Table 4. Concentrations of dissolved free amino acids (DFAA), total dissolved hydrolysable amino acids (DHAA), dissolved organic carbon (DOC) and carbon-normalized amino acid yields (AA yield \%OC) and degradation index based on DHAA for subseafloor basement fluids. Numbers in parenthesis are standard deviations (1SD) of analysis of replicate samples $(n=2-5)$. There is only one CORK $1301 \mathrm{~A}-2009$ sample for DHAA analysis and thus no SD reported.

\begin{tabular}{|c|c|c|c|c|c|c|c|c|c|c|c|c|c|c|c|c|c|c|c|}
\hline \multirow{4}{*}{$\frac{(\mathrm{nM})}{\mathrm{ASP}}$} & \multicolumn{11}{|c|}{ CORK 1301A } & \multirow{2}{*}{\multicolumn{4}{|c|}{$\begin{array}{c}\text { CORK 1362 B } \\
2011\end{array}$}} & \multirow{2}{*}{\multicolumn{3}{|c|}{$\begin{array}{c}\text { CORK 1362A } \\
2011\end{array}$}} & \\
\hline & \multicolumn{3}{|c|}{2009} & \multicolumn{4}{|c|}{2010} & \multicolumn{4}{|c|}{2011} & & & & & & & & \\
\hline & \multicolumn{2}{|c|}{ DFAA $(n=5)$} & \multirow{2}{*}{$\begin{array}{r}\operatorname{DHAA}(\mathrm{n}=1) \\
14\end{array}$} & \multicolumn{2}{|c|}{ DFAA $(n=5)$} & \multicolumn{2}{|c|}{ DHAA $(n=2)$} & \multicolumn{2}{|c|}{ DFAA $(n=4)$} & \multicolumn{2}{|c|}{ DHAA $(n=3)$} & \multicolumn{2}{|c|}{ DFAA $(n=4)$} & \multicolumn{2}{|c|}{ DHAA $(n=3)$} & \multicolumn{2}{|c|}{ DFAA $(n=2)$} & \multicolumn{2}{|c|}{$\overline{\operatorname{DHAA}}(n=2)$} \\
\hline & 1.5 & $(0.2)$ & & - & - & 15 & $(0.0)$ & 0.6 & $(0.1)$ & 10 & $(2)$ & - & - & 9 & (3) & - & - & 2 & (1) \\
\hline GLU & - & - & 13 & 0.9 & $(0.5)$ & 15 & (2.2) & 1.5 & (1.4) & 8 & (3) & - & - & 12 & (2) & - & - & 5 & (1) \\
\hline SER & 6.0 & (1.3) & 16 & 1.7 & (1.1) & 13 & $(0.7)$ & 0.5 & $(0.2)$ & - & - & - & - & 13 & $(0.6)$ & - & - & 7 & (1.1) \\
\hline HIS & 0.8 & (1.1) & 1 & - & - & 1 & $(0.0)$ & 2.1 & $(0.8)$ & 4 & (2) & - & - & 1 & (1) & - & - & 3 & $(0)$ \\
\hline GLY & 2.4 & (1.3) & 19 & 0.5 & $(0.5)$ & 17 & (4.2) & 1.9 & (1.0) & 4 & (5) & 0.96 & $(0.7)$ & 14 & (2) & - & - & 17 & (5) \\
\hline THR & - & - & 5 & 1.2 & (0.8) & 7 & (0.6) & - & - & - & - & - & - & 1.4 & (1.2) & - & - & 1.7 & $(0.6)$ \\
\hline ARG & - & - & 3 & 1.3 & (1.0) & 3 & (1.3) & 0.7 & $(0.8)$ & - & - & - & - & 2.5 & $(0.8)$ & 0.3 & $(0.1)$ & 0.2 & $(0.4)$ \\
\hline ALA & 2.4 & $(0.7)$ & 5 & 0.9 & (1.3) & 2 & (0.9) & 0.2 & $(0.2)$ & 2.1 & (2) & 0.31 & $(0.1)$ & 4 & (3) & 0.5 & $(0.0)$ & 3 & (0.5) \\
\hline TYR & 0.2 & $(0.2)$ & 2 & - & - & 2 & (0.9) & - & - & 0.5 & $(0.5)$ & - & - & 1.1 & $(0.4)$ & - & - & 0.4 & $(0.4)$ \\
\hline MET & - & - & - & 1.9 & (1.6) & - & & 0.3 & $(0.1)$ & 2.3 & (1) & - & - & 0.3 & (0) & - & - & 2 & $(0.2)$ \\
\hline VAL & 0.7 & $(0.9)$ & 4 & - & - & 4 & (1.8) & - & - & 0.9 & (1) & - & - & 1.7 & (1) & - & - & 0.8 & (1) \\
\hline PHE & - & - & 2 & - & - & 2 & (0.9) & - & - & - & - & - & - & 0.2 & $(0.3)$ & - & - & 0.1 & $(0.1)$ \\
\hline ILE & 0.5 & $(0.3)$ & - & & - & - & & - & - & - & & - & - & 1.1 & $(0.3)$ & - & - & 0.1 & $(0.1)$ \\
\hline LEU & - & - & 8 & - & - & 8 & (6.7) & - & - & 3.5 & (2) & - & - & 1.0 & (1) & - & - & - & - \\
\hline LYS & - & - & - & - & & - & & - & - & - & & - & - & & & - & - & - & \\
\hline GABA & - & - & - & - & - & - & - & - & - & 6 & (2) & & - & 0.6 & (0.6) & - & - & 18.0 & (0.4) \\
\hline BALA & - & - & - & - & - & - & - & - & - & 1.1 & (0) & - & - & 0.6 & $(0.6)$ & 0.3 & $(0.0)$ & - & - \\
\hline Total AA (nM) & 14 & (6) & 89 & 9 & (7) & 88 & (20) & 8 & (5) & 43 & (22) & 1 & (1) & 65 & (17) & 1 & (0) & 60 & (12) \\
\hline $\mathrm{DOC}(\mu \mathrm{M}-\mathrm{C})$ & & & 13 & & & 11 & (3) & & & 12 & (1) & & & 11 & (1) & & & 16 & (3) \\
\hline$A A$ yield (\%OC) & & & 2.8 & & & 3.3 & $(0.2)$ & & & 1.7 & $(0.8)$ & & & 2.2 & $(0.7)$ & & & 1.3 & $(0.3)$ \\
\hline Degradation Index & & & 0.7 & & & 1.6 & $(0.2)$ & & & -1.2 & $(0.0)$ & & & -0.1 & $(0.6)$ & & & -1.6 & $(0.0)$ \\
\hline DFAA/DHAA & & & 0.16 & & & 0.10 & $(0.08)$ & & & 0.18 & $(0.14)$ & & & 0.02 & $(0.01)$ & & & 0.02 & $(0.005)$ \\
\hline
\end{tabular}


Table 5. Dissolved free amino acids (DFAA), dissolved hydrolysable amino acids (DHAA) concentrations, carbon-normalized amino acid yields (AA yield \% organic carbon), dissolved organic carbon (DOC), temperature and $\mathrm{pH}$ for hydrothermal fluids and hydrothermal-influenced sediment porewater in various hydrothermal systems.

\begin{tabular}{|c|c|c|c|c|c|c|c|}
\hline Sample type and location & $\begin{array}{c}\text { Temperatur } \\
\text { e }\left({ }^{\circ} \mathrm{C}\right)\end{array}$ & pH & DFAA $(\mu M)$ & DHAA ( $\mu \mathrm{M})$ & $\mathrm{DOC}(\mu \mathrm{M})$ & $\begin{array}{l}\text { DHAA } \\
\text { yield } \\
\text { (\%OC) }\end{array}$ & Reference \\
\hline \multicolumn{8}{|l|}{ Oceanic basaltic basement fluids } \\
\hline $\begin{array}{l}\text { Juan de Fuca eastern flank ( } 3.5 \mathrm{Ma} \\
\text { basement) }\end{array}$ & 65 & $\sim 7.4$ & $0.001-0.014$ & $0.043-0.089$ & $12-16$ & $1.3-3$ & This study \\
\hline \multicolumn{8}{|l|}{ Deep submarine hydrothermal vents } \\
\hline Mid-Atlantic Ridge $30^{\circ} \mathrm{N}$ (Lost City) & $\sim 90^{\mathrm{a}}$ & $9-11^{a}$ & N.A. & $0.736-2.3$ & $\sim 100$ & $2.5-15$ & Lang et al. (2013) \\
\hline $\begin{array}{l}\text { Mid-Atlantic Ridge } 15^{\circ} \mathrm{N} \text { (Logatchev) } \\
\text { and } 4-9^{\circ} \mathrm{S}\end{array}$ & $\sim 350-400$ & $\sim 3.5^{b}$ & $\begin{array}{l}0.038-0.377 \\
\text { (?) }\end{array}$ & N.A. & N.A. & N.A. & Klevenz et al. (2010) \\
\hline $\begin{array}{l}\text { Suiyo Seamount, Izu-Bonin Arc, NW } \\
\text { Pacific (water depth 1400m) }\end{array}$ & 300 & N.A. & N.A. & $0.067-1.082^{c}$ & N.A. & N.A. & Horiuchi et al. (2004) \\
\hline Guaymas Basin (water depth 2000m) & $152-319$ & N.A. & $<0.001$ & N.A. & N.A. & N.A. & $\begin{array}{l}\text { Haberstroh and Karl } \\
\text { (1989) }\end{array}$ \\
\hline \multicolumn{8}{|c|}{ Shallow submarine hydrothermal vents ( 1 m deep) } \\
\hline Baia di Levante, Vulcano, Italy & 88 & 5.6 & $1.33-1.92$ & $0.88-1.86$ & $56-72$ & $10-15$ & Svensson et al. (2004) \\
\hline \multicolumn{8}{|l|}{ Geothermal wells } \\
\hline Vulcano, Italy & $42-81$ & $2-6.3$ & $0.33-78$ & $0.39-35$ & $34-1780$ & $2-25$ & Svensson et al. (2004) \\
\hline \multicolumn{8}{|l|}{ Subterranean hydrothermal vent } \\
\hline Toyoha mine, Hokkaido, Japan & $48-71$ & $5.8-6.6$ & N.A. & 2.6-6.1 & N.A. & N.A. & Takano et al. (2003) \\
\hline \multicolumn{8}{|c|}{ Hydrothermal-influenced marine sediment porewater } \\
\hline $\begin{array}{l}\text { Juan de Fuca eastern flank (sample } \\
\text { depth: } 207-222 \mathrm{~m} \text { ) }\end{array}$ & N.A. & 7.1-7.5 & $0.27-1.46$ & $0.8-3.1$ & $103-229$ & $2.7-6.9$ & This study \\
\hline Guaymas Basin (sample depth: 0-12 cm) & $5-100$ & N.A. & $5-446$ & N.A. & N.A. & N.A. & $\begin{array}{l}\text { Haberstroh and Karl } \\
\text { (1989) }\end{array}$ \\
\hline $\begin{array}{l}\text { Shallow submarine near Japan (sample } \\
\text { depth: } 0-30 \mathrm{~cm} \text { ) }\end{array}$ & $80-104$ & $7.2-7.5$ & $22-196$ & $98-338$ & $\begin{array}{l}2742- \\
4942\end{array}$ & $15-23$ & Hoaki et al. (1995) \\
\hline \multicolumn{8}{|l|}{ Deep seawater $(>1000 m)$} \\
\hline $\begin{array}{l}\text { North Pacific Ocean }\left(22^{\circ} 45^{\prime} \mathrm{N}, 158^{\circ} \mathrm{W}\right)- \\
\text { year } 2001\end{array}$ & N.A. & N.A. & N.A. & $0.05-0.06$ & $36-38$ & $0.4-0.5$ & Kaiser and Benner (2009) \\
\hline $\begin{array}{l}\text { North Pacific Ocean }\left(22^{\circ} 45^{\prime} \mathrm{N}, 158^{\circ} \mathrm{W}\right) \text { - } \\
\text { year } 1991^{\mathrm{d}}\end{array}$ & N.A. & N.A. & N.A. & 0.109 & 41 & 0.51 & McCarthy et al. (1996) \\
\hline North Pacific Ocean $\left(31^{\circ} \mathrm{N}, 159^{\circ} \mathrm{W}\right)$ & N.A. & N.A. & $0.2-1.1$ & $0.09-0.159$ & $34-36$ & $0.9-1.6^{\mathrm{e}}$ & Druffel et al. (1992) \\
\hline $\begin{array}{l}\text { North Pacific Ocean }\left(2^{\circ} \mathrm{N}, 101^{\circ} \mathrm{W} ; 0^{\circ} \mathrm{S},\right. \\
\left.85^{\circ} \mathrm{W}\right)\end{array}$ & N.A. & N.A. & $\sim 0$ & $0.08-0.18$ & N.A. & N.A. & Lee and Bada (1975) \\
\hline
\end{tabular}

N.A.: Not available.

a: Temperature and $\mathrm{pH}$ derived from Lang et al. (2010).

b: $\mathrm{pH}$ derived from Schmidt et al. (2007).

c: End-member fluid compositions calculated based on data from Horiuchi et al. (2004)

d. McCarthy et al. reported only the ultrafiltered fraction (>1000 Dalton) of the dissolved organic carbon.

e. AA yield calculated based on an average of 3.8 carbon per amino acid. 
Figure 1.

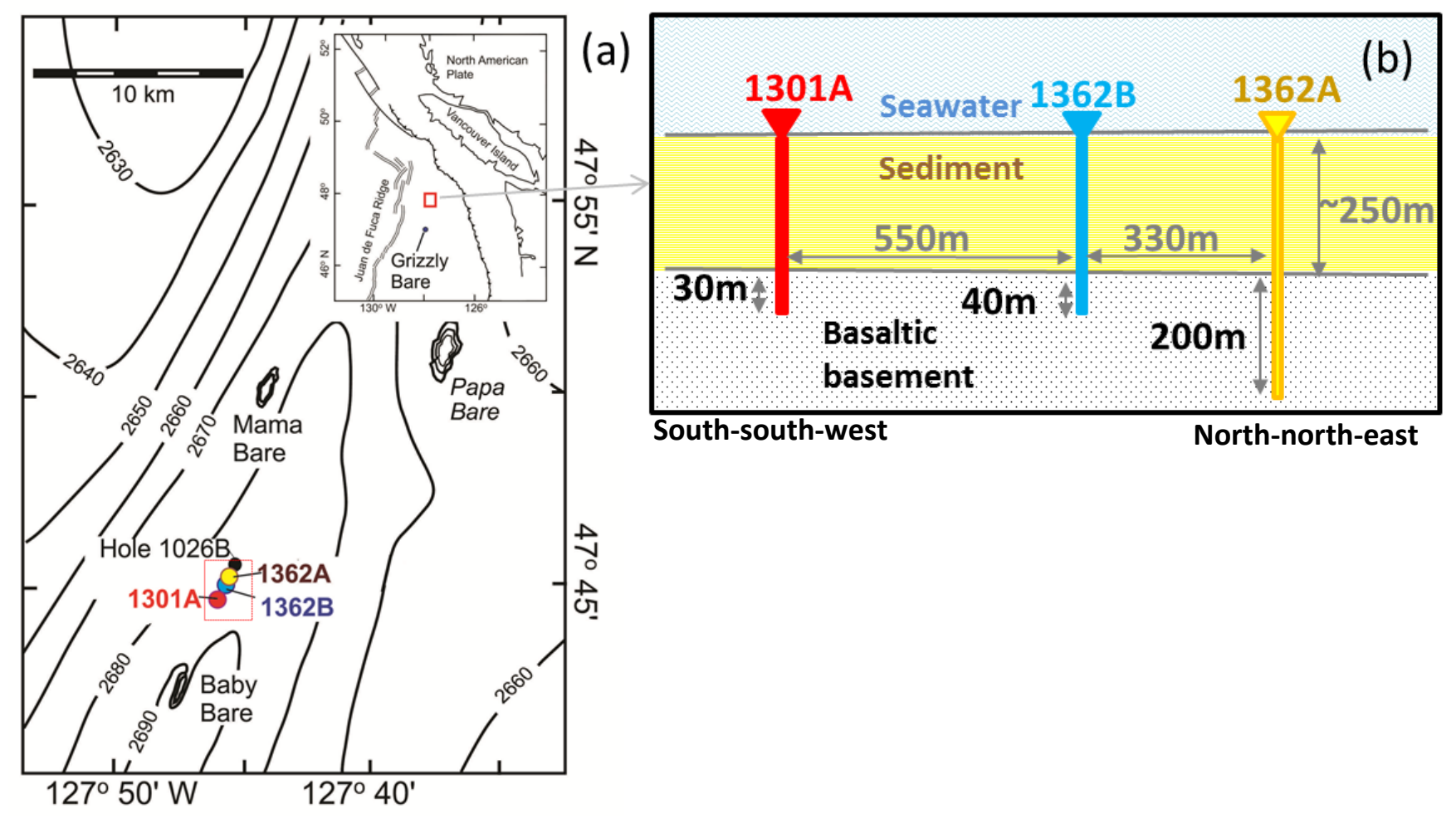

(Color version is for on-line publication. Black and white in print) 
Figure 2.
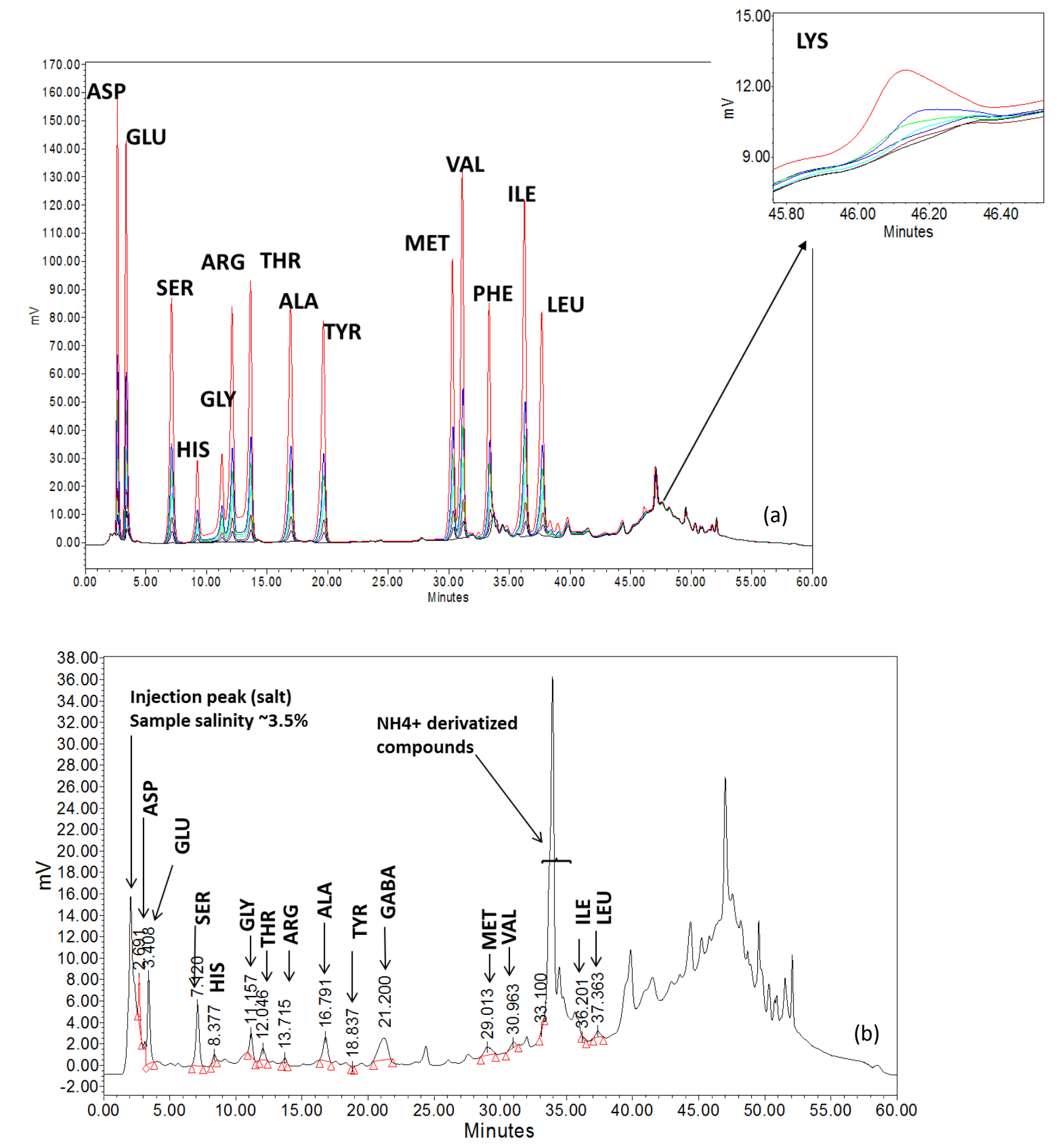

(Color version is for on-line publication. Black and white in print) 
Figure 3.

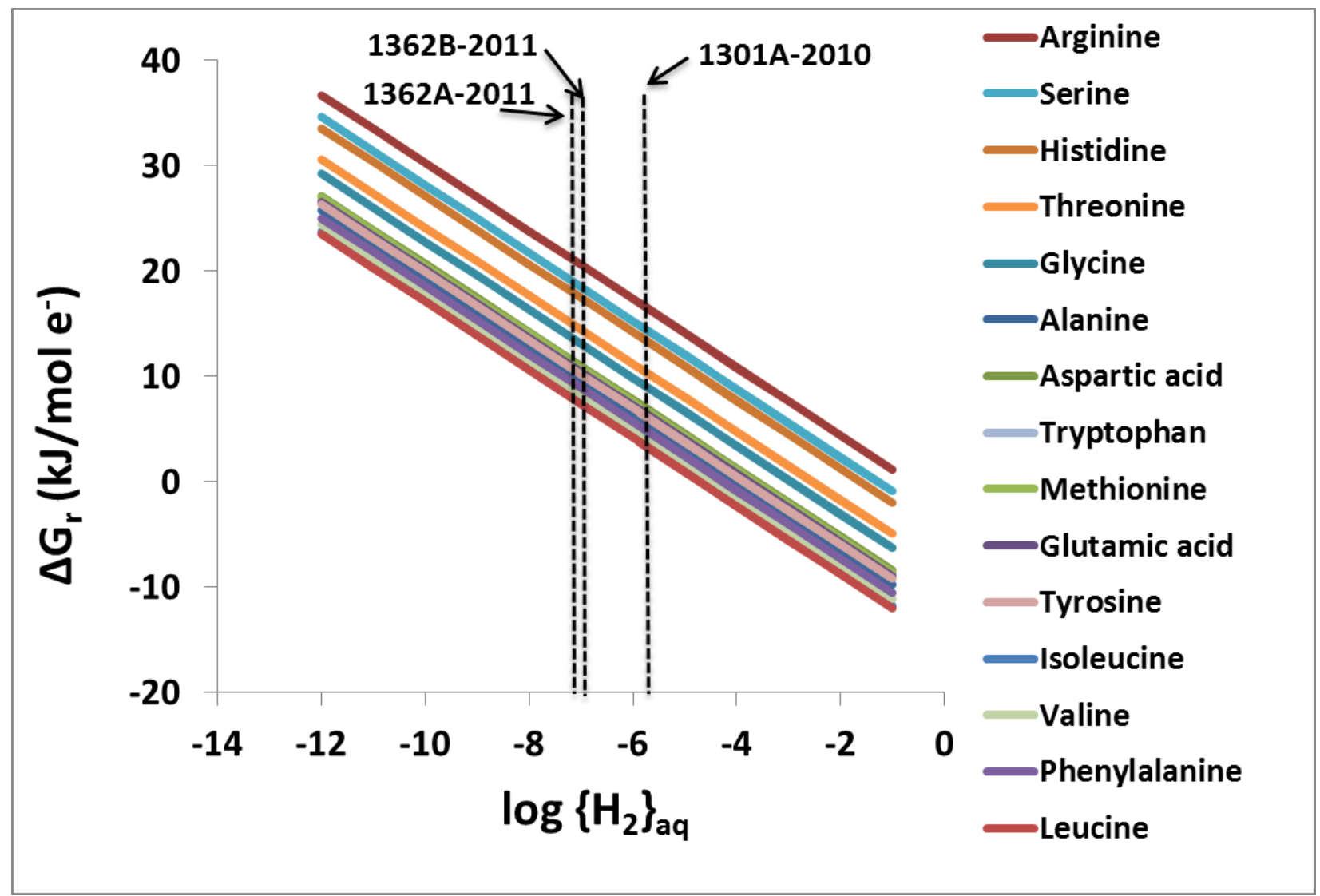

(Color version is for on-line publication. Black and white in print) 
Figure 4.

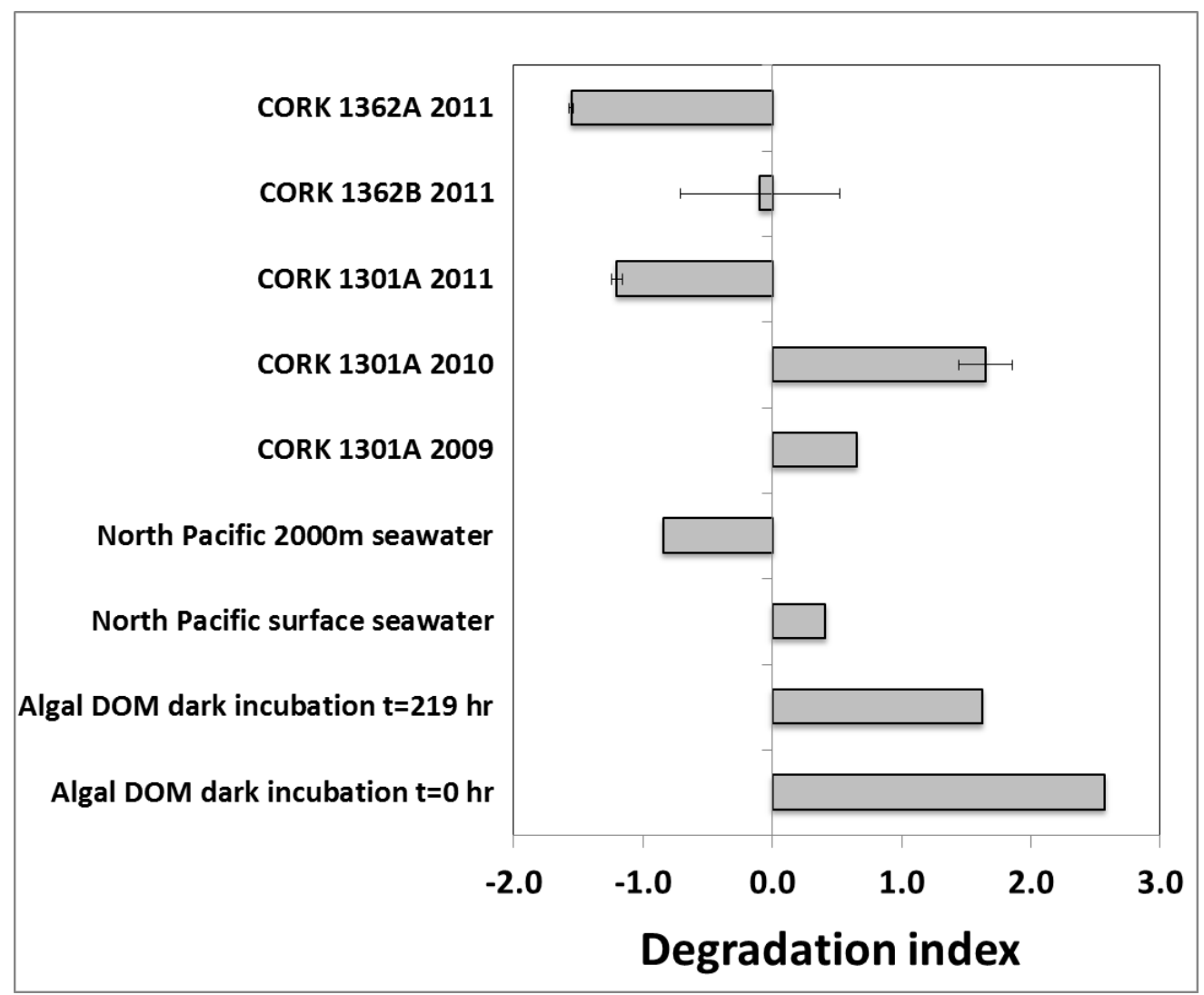


Figure 5.
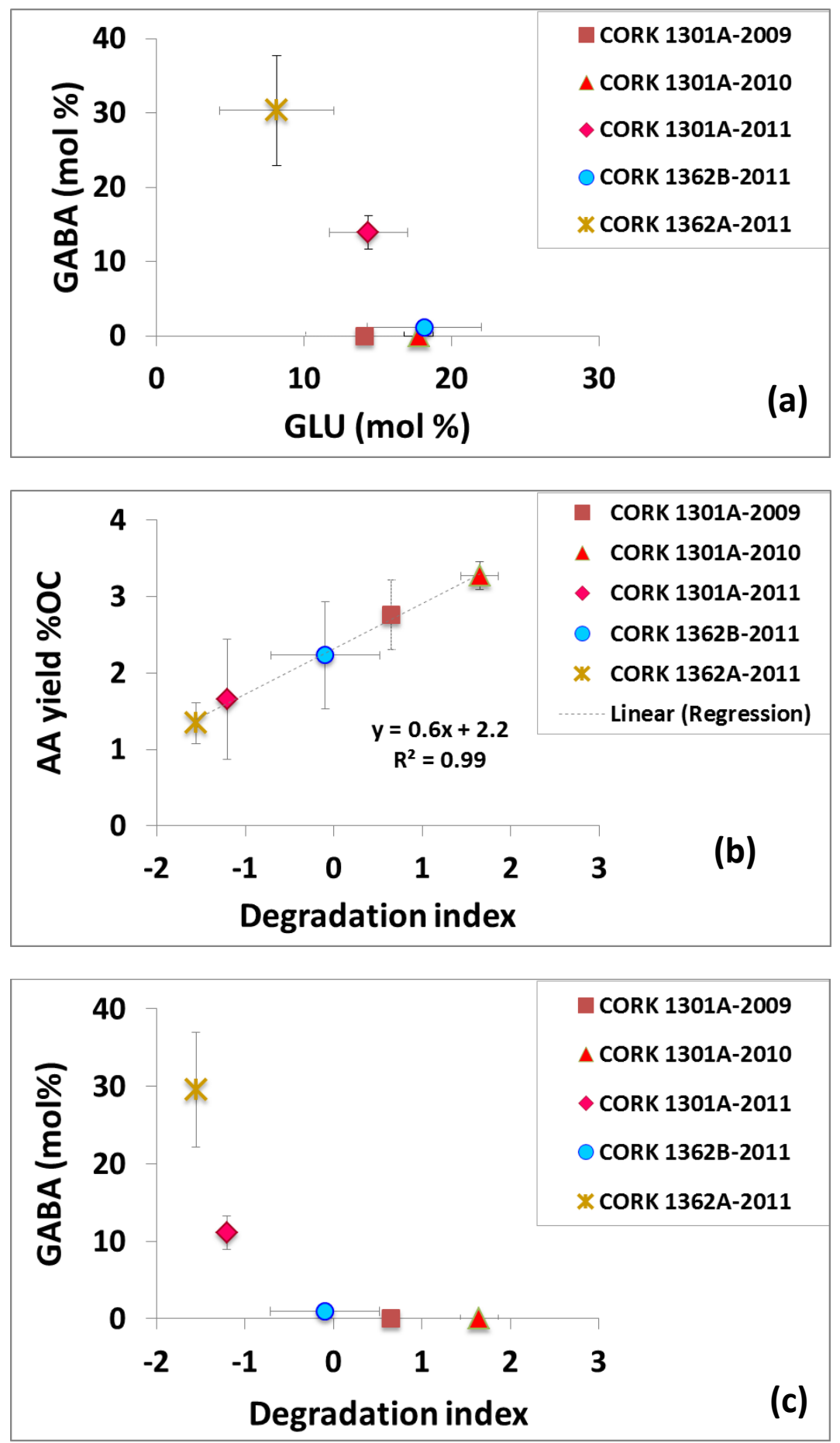

(Color version is for on-line publication. Black and white in print) 
Figure 6.

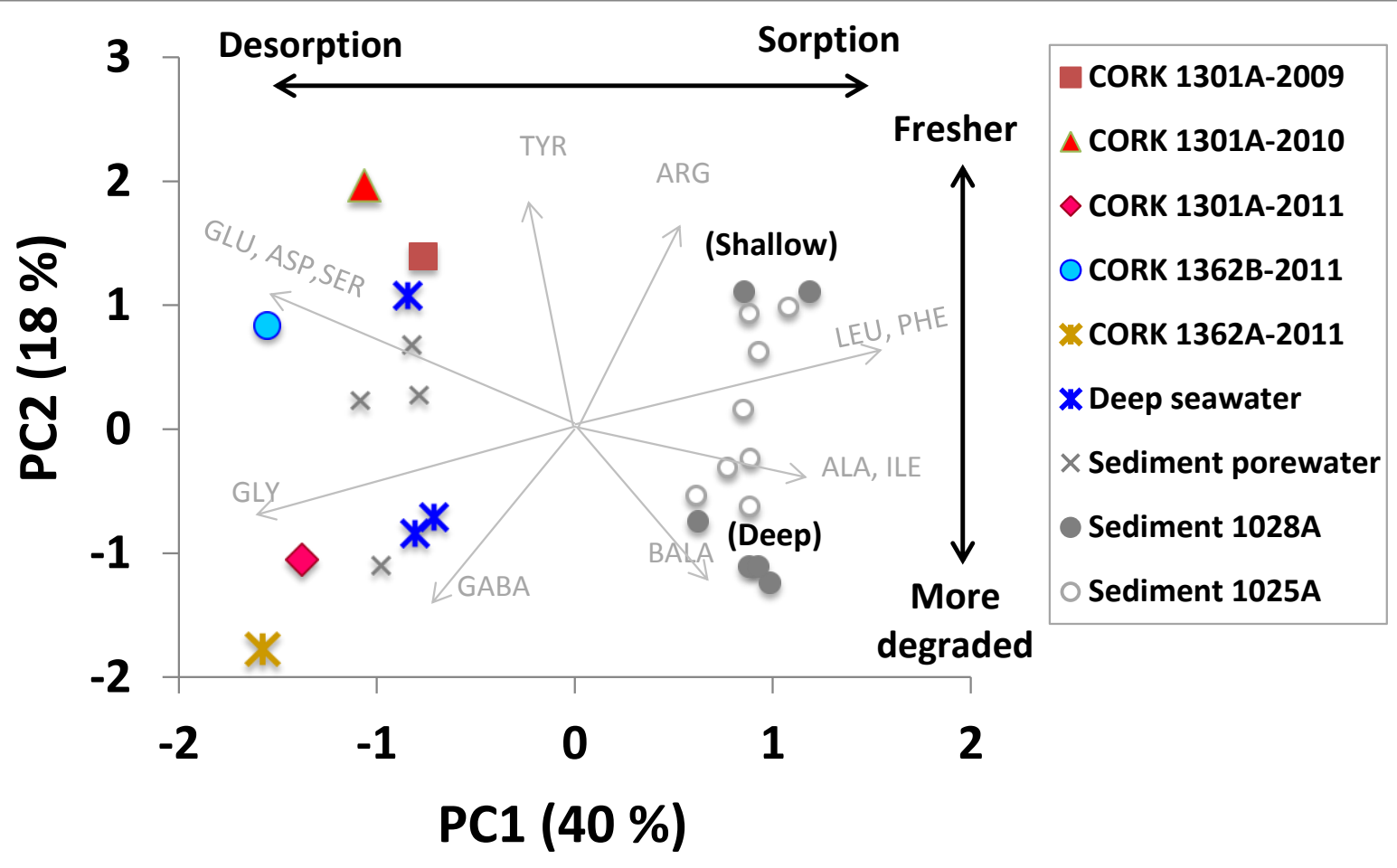

